\title{
ENTRE KANT E NEGRI: UM CAMINHO DO COSMOPOLITISMO AO “COMUMPOLITISMO"
}

\section{Fernando Hoffmam ${ }^{1}$}

\begin{abstract}
RESUMO: O presente trabalho propõe analisar o caminho a ser percorrido a partir do cosmopolitismo kantiano, até se chegar ao que se denomina "comumpolitismo" como um novo lugar para os direitos humanos na atualidade. Nesse passo, busca-se desvelar as raízes modernas, limitadas e excludentes dos projetos cosmopolitas de Immanuel Kant e Otfried Höffe, determinando sua ligação com o estatalismo, e sua apreensão pelo "Império", bem como propondo um projeto cosmopolita alternativo. Desse modo, a partir da construção teórica de Antonio Negri, partindo-se da ideia de "comum" como um novo sujeito político a partir da "multidão", propõe-se a construção do "comumpolitismo" ou "cosmopolitismo do comum" como um projeto cosmopolita alternativo, inclusivo, coletivo e plural, conformado na prática cotidiana da "multidão", instituindo-se como um novo lugar para os direitos humanos e para os movimentos da "multidão do comum" enquanto práticas revolucionárias, antagonistas e de resistência. Nesse sentido, objetiva-se apresentar o "comumpolitismo" como um projeto possível e como ambiente para os direitos humanos hoje, alternativamente aos projetos cosmopolitas estatalistas ou "imperiais". Para tanto, elege-se como método de abordagem o método analético (ana-lético), como um método que parte do outro totalmente livre, do outro, estando além do sistema da totalidade compreendido dialeticamente no movimento (moderno/pós-moderno).
\end{abstract}

PALAVRAS-CHAVE: Cosmopolitismo. "Comumpolitismo". "Comum”. Direitos Humanos.

\section{INTRODUÇÃO}

O presente artigo, busca analisar os projetos cosmopolitas predominantemente existentes, como projetos modernos, ou, ligados a modernidade, bem como, inseridos na lógica "imperial" comum ao tempo presente, dessa maneira, relacionando o cosmopolitismo ou com a estatalidade, ou, com as estruturas imperiais, percorrendo um caminho da modernidade à atualidade. Nesse passo, busca-se desvelar esses projetos cosmopolitas, propondo-se um projeto alternativo de cosmopolitismo que se compatibilize com a complexidade contemporânea, e que se coloque verdadeira e efetivamente como um lugar para os direitos humanos atualmente.

\footnotetext{
${ }^{1}$ Doutor e Mestre em Direito Público pela Universidade do Vale do Rio dos Sinos (UNISINOS); Bolsista PROEX/CAPES; Membro do Grupo de Pesquisa Estado e Constituição e da Rede Interinstitucional de Pesquisa Estado e Constituição, vinculados à FDV/ES, à ESDHC/MG e ao CNPQ; Professor Adjunto I do Curso de Direito da Universidade Federal de Santa Maria (UFSM); Especialista em Direito: Temas Emergentes em Novas Tecnologias da Informação e Bacharel em Direito pelo Centro Universitário Franciscano (UNIFRA). Universidade Federal de Santa Maria (UFSM/RS) - Brasil. E-mail: ferdhoffa@yahoo.com.br
} 
Para tanto, percorre-se o caminho do cosmopolitismo e dos projetos cosmopolitas a partir de Immanuel Kant e seu projeto para a paz perpétua, vislumbrando um direito de visitação e um direito à hospitalidade que seria universal. No entanto, ao analisar esse projeto de cosmopolitismo empreendido por Kant, se busca no presente trabalho desvelar a sua intrínseca relação com a modernidade europeia, como também, como o humanismo moderno-europeu, que deixa do lado de fora da humanidade um sem fim de sujeitos que não são vistos como racionais, civilizados e dignos de proteção (Parte 1).

Nesse caminho, chega-se até a construção teórica de Otfried Höffe, que a partir do projeto para a paz perpetua de Kant, avança em direção ao projeto de uma república mundial cosmopolita, que seria subsidiaria e federativa, buscando de maneira ampla e múltipla a garantia dos direitos humanos em escala global. No entanto, o projeto cosmopolita hoffeniano permanece ligado a estatalidade, bem como, se mostra limitado quanto a apreensão do pluralismo social existente, no que tange, sobretudo, aos povos esquecidos pela modernidade e pelo projeto cosmopolita kantiano, logo, implicando necessariamente em limites no que tange a proteção e concretização dos direitos humanos de maneira global e plural (Parte 2).

Desse modo, mostra-se necessário a construção de um novo lugar para os direitos humanos na atualidade, o que se dá a partir da constituição do "comum" como um novo sujeito político que nomeia a "multidão" e conforma um "estar-em-comum" das singularidades na sua multiplicidade. A partir desse novo sujeito político se origina um novo projeto cosmopolita, qual seja o "comumpolitismo" ou "cosmopolitismo do comum" enquanto um novo ambiente para os direitos humanos e para as humanidades expropriadas pelo "Império" (Parte 3).

Nesse sentido, elege-se como método de abordagem o método analético (ana-lético), como um método que parte do outro totalmente livre, do outro, estando além do sistema da totalidade compreendido dialeticamente no movimento (moderno/pós-moderno). "O método analético é a passagem ao justo crescimento da totalidade desde o outro e para 'servi-lo' criativamente". (DUSSEL, 1986, p. 196). Com o uso do método analético, busca-se a possibilidade de compreensão do outro como exterioridade do sistema, para além da totalidade que o consagra como outro, como excluído. Assim, objetiva-se a compreensão do "comumpolitismo" como projeto alternativo ao cosmopolitismo estatalista ou "imperial", em um movimento para além da totalidade assujeitadora do Estado ou do "Império".

\section{O PROJETO COSMOPOLITA KANTIANO E A IDEIA DE PAZ PERPÉTUA}


Há sim um dado cosmopolitismo que surge na modernidade ${ }^{2}$ e tem suas bases construídas a partir de um projeto moderno de organização política, jurídica e social, bem como, de uma determinada institucionalidade, qual seja, o Estado, e de certas características que alicerçam o empreendimento moderno. Sem dúvida alguma, a principal característica que guia a modernidade e o projeto cosmopolita que se elabora nela, é a racionalidade, ou, a aposta da razão humana como um universal que organiza e rege o mundo enquanto lugar da humanidade.

Nesse passo, constitui-se um projeto moderno de humanidade que engendra evidentemente um projeto de Direito, seja no âmbito interno/nacional, seja no âmbito externo/internacional, e que corrobora com uma determinada apreensão da humanidade e com uma determinada operação sobre o fenômeno jurídico, político e social. Essas articulações modernas propiciam uma série de projetos $\mathrm{e}$, sobremodo, um projeto destinado à paz mundial, ou, à paz entre os Estados e um determinado Direito da guerra, ou, sobre a guerra que se inicia com Grotius e Francisco de Vittoria ${ }^{3}$ e resulta na chegada a um outro desenho que é o projeto kantiano para a paz perpétua.

O que interessa ao presente artigo é especificamente a construção teórica kantiana a respeito do cosmopolitismo englobando a sua ideia de paz perpétua que consubstancia todo o arranjo cosmopolita proposto pelo autor Immanuel Kant. Desse modo, é importante demarcar a proposta kantiana e a suas intenções de construir um ambiente de paz mundial para a humanidade e o desenvolvimento completo de seus valores humanos e da racionalidade humana como um plano ideal de desenvolvimentos das capacidades e das singularidades em um contexto de respeito à humanidade, proteção e concretização de direitos naturais intrinsecamente ligados a essa condição humana que racionalmente se constitui como um valor moral universal.

Nesse sentido, Immanuel Kant (1724-1804) ergue seu projeto sobre a necessidade de se pensar e normatizar um conjunto de regras que visassem à paz mundial, a partir da publicação em 1784 originalmente, da obra intitulada "Ideia de Uma História Universal de um Ponto de Vista cosmopolita" e, mais tarde, já na sua maturidade intelectual, em certa medida complementa esse projeto cosmopolita para a paz mundial com a obra "À Paz Perpétua" originalmente publicada em 1795. Evidentemente, a obra de Immanuel Kant como um todo, deixa contribuições importantes ao

\footnotetext{
${ }^{2}$ Evidentemente o cosmopolitismo não começa aqui, mas na Modernidade, se inicia um projeto cosmopolita que reúne determinadas características e se coloca no mundo enquanto teoria a partir de determinados pressupostos que o diferenciam do cosmopolitismo anterior, seja em Roma, Grécia, com os cínicos ou no estoicismo. No entanto, tais períodos não serão trazidos no presente trabalho, pois, se opta por um recorte sobre o(s) cosmopolitismos(s) a partir do projeto cosmopolita kantiano, chegando até alguns autores contemporâneos. Sobre os períodos anteriores, ver, entre outros: (SALDANHA, 2018); (NASCIMENTO, 2011); (GAZOLLA, 1999); (GOULET-CAZÉ; BRANHAM, 2007).

${ }^{3}$ Aqui, cabe referir que, embora, nesses autores já se constituam projetos a respeito da consecução da paz mundial, da paz entre os Estados, entre nações, num espectro internacional, ou seja, a partir do direito internacional, não é esse o tema do trabalho, e, por esse motivo, opta-se por não trabalhar tais autores. Contudo o trabalho aborde sim, um projeto par a paz mundial, ele aborda um projeto especifico, qual seja, o kantiano da paz perpétua e seus desdobramentos teóricos até a contemporaneidade.
} 
desenvolvimento de sua concepção de cosmopolitismo, embora, essas duas obras sejam as obras centrais no desenvolvimento teórico kantiano a respeito do cosmopolitismo.

Dando prosseguimento, em "Ideia de Uma História Universal de um Ponto de Vista cosmopolita" Kant constrói e apresenta nove (9) proposições acerca da humanidade e de uma ideia cosmopolita sobrea perseguição da paz em nível mundial, para a humanidade. Já na terceira proposição, Kant elucida que o homem por meio da razão deve buscar a felicidade ou perfeição que ele proporciona a si mesmo, mas de maneira livre do instinto, ou seja, de forma racional de modo que a busca da sua felicidade em certa medida implique chegar-se a um bem como, pois, essa busca não se dá instintivamente, mas racionalmente. (KANT, 2011). Retrocedendo momentaneamente à primeira proposição, já se nota que para Kant as disposições naturais atinentes a um indivíduo estão sempre orientadas à consecução de um fim, o homem dotado de razão deve buscar sempre desenvolver-se completamente enquanto ser humano (racional) de acordo com um fim (KANT, 2011), "pois, se prescindirmos desse princípio, não teremos uma natureza regulada por leis, e simum jogo sem finalidade da natureza e uma indeterminação desconsoladora toma o lugar do fio condutor da razão”. (KANT, 2011, p. 5).

Veja-se que nesse ponto, já é clara a ligação da possibilidade de construir-se uma sociedade cosmopolita, ou, uma instituição cosmopolita, qual seja essa, está intrinsecamente ligada em Kant ao homem ser um animal dotado de razão. Desse modo, a racionalidade humana é condição de possibilidade para que os homens, justamente por regerem suas condutas de acordo com um princípio que os faz através delas buscarem sempre o atingimento de um fim, que sob uma perspectiva cosmopolita kantiana seria a percepção da humanidade sob um ponto de vista cosmopolita. Vislumbra-se todo ao arcabouço jurídico-político kantiano a partir do cosmopolitismo como um fim a ser atingido pelo homem racionalmente a partir de suas condutas que através da razão o conduzem a uma institucionalidade que mundialmente siga esse princípio e respeite a própria humanidade - do homem racional moderno.

Nesse passo, se formula a possibilidade do surgimento de um direito cosmopolita, um direito das gentes que conforme a humanidade como um todo universal que eticamente se coloca e se comporta no mundo, tendo como fim último a paz (perpétua) mundial. Kant (2008) é claro ao afirmar que o direito entre os estados deve partir da perspectiva de também retirar os Estados de um estado de natureza entre eles, semelhante ao qual são retirados os indivíduos quando se organizam em forma de sociedade - sob a forma política do Estado Moderno. Embora, para Kant (2008) haja um direito de ir à guerra, também há um direito à paz, e essa paz deve ser o fim máximo dos Estados - e dos indivíduos - organizados de maneira a formarem uma "sociedade de estados" que se orienta 
pela busca e pela preservação da paz, garantindo o direito a um Estado ser neutro em relação a um conflito vizinho e manter a sua neutralidade.

Retomando a "Metafísica dos Costumes" é necessário perceber quer há uma ligação indissociável entre o atingimento da paz perpétua como o cumprimento do imperativo categórico, como posto pelo autor na obra citada, sendo um imperativo da razão no sentido de guiar-se por ele em direção a uma lei moralmente prática. Com base em Kant, pode-se dizer que chegar a um direito cosmopolita que apazigue os conflitos entre as Nações é um imperativo categórico incondicional, que deve ser cumprido, pois, representa uma ação como objetivamente necessária. (KANT, 2008). Nesse sentido, tem-se como princípio máximo da doutrina dos costumes, e, se pode dizer, da constituição de uma sociedade - Estado - entre os homens "age com base em uma máxima que pode também ter validade como uma lei universal". (KANT, 2008, p. 26), e sob essa perspectiva se busca em Kant construir um direito orientado por essa máxima, bem como, instituir o direito cosmopolita, ou, direito entre os estados como uma máxima derivada desse princípio no sentido de possibilitar um fim comum para os direitos das gentes.

Dessa forma, para Kant, "o direito é, portanto, a soma das condições sob as quais a escolha de alguém pode ser unida à escolha de outrem de acordo com uma lei universal de liberdade" (2008, p. 76), pois, claramente os seres humanos devem ser orientados por um princípio de liberdade, ou, que os conduza à liberdade calcado numa perspectiva de coexistência ética com o outro. Porquanto, a lei universal do direito para Kant é "age externamente de modo que o livre uso do teu arbítrio possa coexistir com a liberdade de todos de acordo com uma lei universal”. (KANT, 2008, p. 77). Fica evidente que o direito kantiano está totalmente ligado ao arbítrio humano e, necessariamente ao uso da razão, o que faz com que o direito apareça como um produto da razão humana com o intento de se chegar à uma máxima liberdade entre os homens.

Nessa medida, tem-se o direito conceituado como um conjunto de condições sob as quais o arbítrio, a vontade de um cidadão, pode agregar-se com o arbítrio do outro, de acordo com uma lei universal da liberdade que vise garantir tanto os direitos de um, quanto do outro, mas sempre respeitando suas liberdades individuais. (NOUR, 2013). A partir desse conceito de direito, Kant apresenta seu princípio universal, ou seja, o critério do que é justo, considerando ser justa toda ação que permite que a liberdade do arbítrio de cada um coexista com a liberdade de qualquer outro, segundo uma lei universal. (NOUR, 2013).

Para Zanella (2012) a teoria cosmopolita de Kant visa assegurar uma condição que esteja em comum acordo com o direito de liberdade de todos os homens, sendo que uma constituição civil de indivíduos, o Estado, tem como objetivo alcançar essa meta entre as pessoas unidas por um território compartilhado. De acordo com Kant (2010a) a comunidade que se foi estabelecendo entre 
os povos, chegou até o ponto de que uma violação do direito cometida em um determinado lugar repercutisse nos demais, o que nos leva a concluir que a ideia do direito, do cidadão mundial, não é uma fantasia jurídica, mas um complemento fundamental do Código não escrito do direito político e do das gentes, que se eleva à categoria do direito público da humanidade, sendo condição necessária para que possa nutrir a esperança de uma aproximação do estado pacífico.

Conforme explica Kant, com uma aproximação dos homens unidos por princípios em comum, e com o aumento da cultura, se chegaria a entendimentos pacifistas, conquistando um equilíbrio das forças ativas, lutando juntamente para uma sociedade melhor .(KANT, 2010a). Nesse sentido Goyard-Fabre (2006) explicita que o projeto de paz mundial kantiano e sua compreensão sobre o direito das gentes e a necessidade de se pensar o direito dos povos, num ambiente pacífico de inter-relação entre os Estados, compreende um projeto totalmente válido e não utópico que tendo dois lados, a partir das "perspectivas teleológicas do direito das gentes, para o qual a Ideia de paz se define como um horizonte de exigência e de esperança; do outro lado, nas perspectivas institucionais do direito internacional, para o qual uma Constituição cosmopolítica perfeita seria uma 'abertura para o infinito"”. (GOYARD-FABRE, 2006, p. 183-184). Nesse contexto, Kant relaciona diretamente a possibilidade de constituição de uma "institucionalidade mundial" para a persecução da paz perpetua entre os Estados ao conceito de soberania e ao uso da soberania por parte dos Estados. Para Kant a soberania era o direito mais importante entre os Estados e, por esse motivo, ele analogicamente compara as relações interestatais à comunidade. humana pré-política, ou seja, ao estado de natura no que tange aos indivíduos.

Nesse interim, Kant (2010b) traça em "À Paz Perpétua",4 seis (6) artigos preliminares e três (3) artigos definitivos como orientação necessária à obtenção da paz perpétua entre os Estados, de modo a construir sua teoria a respeito da "Paz Perpétua". Nesse sentido, proclama Kant já no primeiro artigo preliminar que nenhum tratado de paz sobre o qual recaírem reservas no sentido de uma outra possível guerra futura deve ser tomado como tal (KANT, 2010b), ou seja, os tratados de paz devem ser celebrados buscando realmente atingir um "estado de paz" entre as Nações, e não possibilitar qualquer tipo de conflito armado futuro. No segundo artigo preliminar, o autor refere que nenhum Estado que seja independente, independentemente de seu tamanho no que tange à sua extensão, mas também ao seu poder no cenário internacional pode ser adquirido por outro Estado seja por herança, troca, compra ou doação (KANT, 2010b), o que deixa claro que não se pode permitir qualquer tipo de dominação por parte de um Estado sobre o outro seja através da guerra como do poderio econômico.

\footnotetext{
${ }^{4}$ Quanto à utilização dessa obra no presente trabalho, convém mencionar que se está a utilizar duas traduções da mesma para o português, bem como, duas edições diversas, por isso, a citação como (KANT, 2010a) e (KANT, 2010b).
} 
Como uma tentativa evidente de eliminar qualquer possibilidade de guerra, e até mesmo de se pensar num horizonte de busca pela paz perpétua mundial em um direito da/há guerra - a guerra justa - Kant defende no terceiro artigo preliminar a definitiva eliminação de exércitos permanentes, bem como, no quarto artigo defende que não deve o Estado fazer dívidas públicas sobre interesses externos do Estado, no sentido de que não se opor a partir de sistemas de crédito e poderio econômico-financeiro uma potência contra a outra (KANT, 2010b). No quinto artigo preliminar Kant expõe que nenhum Estado deve interferir com emprego da força na constituição e no governo de um outro Estado, o que mostra que para o autor nenhum Estado teria um direito à guerra, à pela força intervir em questões internas atinentes a outro ente estatal, política e juridicamente. (KANT, 2010b). No sexto artigo preliminar, Kant defende que mesmo em guerra nenhum Estado pode empregar contra o outro, meios tais que impliquem um nível de hostilidade que impossibilite no período pós-conflito que se acredite reciprocamente na paz futura, e, enumera de maneira não exaustiva o que seriam meios que levariam a tal situação, como o emprego de assassinos, envenenadores, instigação à traição, etc. (KANT, 2010b).

Note-se que pela leitura dos seis artigos preliminares é bastante notório que o projeto kantiano para se alcançar à paz perpétua está diretamente ligado a um determinado paradigma no que tange à organização política de dada sociedade, qual seja, o estatalismo moderno, haja visto todas as formulações até aqui estarem claramente ligadas à relação entre Estados na esfera internacional, o que torna o cosmopolitismo um fenômeno afeito à Estados e cidadãos - sob um ponto de vista moderno-europeu.

Nessa maré, Kant no segundo artigo definitivo para a paz perpétua enuncia que o direito internacional deve se organizar sob a forma de um federalismo de Estados livres, ou seja, deve constituir-se a partir de uma federação de Estado livres, ou, uma federação de povos livres. Como já referido, assim como no estado de natureza se abriria mão de um certo grau de autonomia e livre arbítrio em favor de um bem maior e a consecução do bem comum dos cidadãos, na federação de Estados livres, esses abririam mão de um certo grau de soberania sem descaracterizarem-se enquanto Estados em nome do atingimento da paz perpétua entre os povos, entre os Estados sem que se forme um Estado de povos, ou um único povo, mas, todos transigindo em direção à paz mundial. (KANT, 2010b).

A federação teria assim, um caráter pacifista e objetivaria acabar com todas as guerras, ou, com a possibilidade de haver guerras já que os estados livremente em prol da paz mundial e perpétua abririam mão do seu direito à guerra, mesmo não desconsiderando a sua soberania. (ZANELLA, 2012). Desse modo, essa organização internacional do direito e da política no âmbito estatal é parte constitutiva do projeto cosmopolita kantiano. O cosmopolitismo em Kant é possível, ou, se origina 
ao redor dessa federação de Estados livres que tem norte fundamental guiar-se por uma perspectiva cosmopolita, baseando o cosmopolitismo kantiano no direito individual e no direito internacional

Seguindo esse pensamento de que deve haver sempre a expectativa na busca pela paz e por dignas condições de vida para toda comunidade, Kant tratou do direito cosmopolita aludindo que o mesmo deve respeitar às condições de hospitalidade universal, ou seja, considerando que a hospitalidade consiste em não tratar qualquer estrangeiro que se encontre em outro país como se fosse um inimigo, um estranho perigoso. (KANT, 2010a). Em um dos seus artigos definitivos, Kant ilustra que a paz não é o estado de natureza do homem, mas sim, a guerra o é. Para tanto, não basta que se evite que as hostilidades iniciem, mas, os Estados devem garantir segurança à sociedade, e, assim, a paz deve ser buscada. (KANT, 2010a). No terceiro artigo definitivo da Paz Perpétua, Kant fala do direito cosmopolita no tratamento ao estrangeiro, que deve ser tratado com hospitalidade:

Significa hospitalidade o direito de um estrangeiro de não ser tratado hostilmente pelo fato de ter chegado ao território alheio. Este pode repeli-lo se a repulsa não for causa da ruína do recém-chegado; mas enquanto o estrangeiro se mantenha pacificamente no lugar, não é possível hostilizá-lo. (KANT, 2010a, p. 59).

Nessa linha, tem-se a hospitalidade como um direito que pertence a todos os seres humanos, na medida em que são considerados como participantes de uma "república mundial", e não como uma virtude de sociabilidade, um benefício que mostramos aos forasteiros que viajam a outro Estado que não o seu de origem em decorrência de circunstâncias naturais ou históricas. O direito de ter direitos, hoje, significa o reconhecimento que cada pessoa deve ter na condição de ser humano, independentemente da sua cidadania e nacionalidade. O direito de hospitalidade delimita e regula as relações entre os membros de um Estado e os estrangeiros que se encontram sob sua jurisdição, ocupando um espaço entre os direitos humanos e os direitos civis, entre o direito da humanidade e do indivíduo, e nos pertencem na medida em que fazemos parte de repúblicas específicas $^{5}$. (BENHABIB, 2004).

Nesse caminho, Kant estabelece o direito das gentes ${ }^{6}$ sob uma perspectiva transcendental do direito que numa escala mundial objetiva a constituição da ordem pública do planeta e da paz

\footnotetext{
${ }^{5}$ E, eis aqui a importância que Kant dá ao republicanismo como a forma organizacional originaria enquanto constituição civil de um Estado, e sendo condição de possibilidade para a fundação de um efetivo Estado de Direito, já no primeiro artigo definitivo para a paz perpétua. "A constituição instituída primeiramente segundo os princípios da liberdade dos membros de uma sociedade (como homens), em segundo lugar, segundo os princípios de dependência de todos, a única legislação comum (como súditos) e, terceiro, segundo a lei da igualdade dos mesmos (como cidadãos) - a única que resulta da ideia de contrato originário, sobre o qual tem de estar fundada doa legislação jurídica de um povo - é a constituição republicana”. (KANT, 2010b, p. 24).

${ }^{6}$ Nesse ponto, é preciso elencar quatro (4) elementos do direito das gentes na formulação kantiana: “1) as relações que os Estados reciprocamente tem travado entre si não são jurídicas; 2) trata-se de um estado de guerra (do direito do mais forte), mesmo que não haja guerra efetiva; 3) é necessária uma aliança entre os povos (Völkerbund),
} 
num sentido universal. Assim, se origina a terceira parte do humanismo kantiano assentado numa ordem mundial de Estados que visa, sobretudo, a garantia primeira da humanidade enquanto uma "comunidade de destino". Central nesse ponto da filosofia kantiana, como em toda a sua construção teórica segue sendo o homem e sua condição humana, bem como, a razão humana e as suas possibilidades de constituir um bem comum universalmente considerado. (GOYARD-FABRE, 2006). Com efeito:

Por conseguinte, pelo conceito geral de direito público somos levados a pensar não só no direito de um Estado, como também num direito das gentes (ius gentium). Visto que a superfície da Terra não é limitada, mas circunscrita, os conceitos de direito do Estado e de direito das gentes conduzem inevitavelmente à ideia do direito de todas as gentes (ius gentium) ou direito cosmopolita (ius cosmpoliticum). (KANT, 2008, p. 153-154).

Para Kant, os membros dessa sociedade organizada politicamente sob a forma de república constituem-se enquanto cidadãos dessa comunidade política republicana, e na condição de sujeitos de direitos, têm como direitos básicos indissociáveis da sua essência de cidadãos três atributos, quais sejam: a liberdade legal devendo obedecer somente às leis com as quais consentiu; a igualdade civil que lhe confere a prerrogativa de não se reconhecer inferior a ninguém em meio ao povo de modo que possa obrigá-lo juridicamente sem que ele possa também obriga-lo; e a independência civil pela qual garante a existência e preservação aos seus próprios direitos e poderes enquanto cidadão e membro da coisa pública. (KANT, 2008).

Note-se, nesse ponto, que o direito cosmopolita esta determinantemente ligado às considerações sobre o direito individual de cada cidadão, pois, esses princípios republicanos de respeito do indivíduo numa perspectiva interna estatal, também podem e devem ser estendidos à condição do cidadão sob o prisma do direito internacional. O direito civil, o direito das gentes e o direito cosmopolita se orientam pelos mesmos princípios republicanos e fundam um direito que é eminentemente racional, liberal e individual, pois, a busca pela paz perpétua entre os Estados em nível mundial, se dá a partir da relação entre os indivíduos. Com efeito:

Já que agora a comunidade (mais estreita, mais larga), difundida sem exceção entre os povos da Terra, foi tão longe que a infração do direito em um lugar da Terra é sentido em todos, não é, assim, a ideia de um direito cosmopolita nenhum modo de representação fantasioso e extravagante do direito, mas um complemento necessário do código não escrito, tanto do direito do Estado como do direito internacional, para um direito público dos homens em geral e, assim, para a paz

conforme a Ideia de um contrato social originário; 4) esta aliança não deve conter um poder soberano, mas ser só uma associação (Genossenschaft) ou uma federação (Föderalität), que pode ser renovada de tempos em tempos". (NOUR, 2013, p. 49). 
perpétua, da qual se pode aprazer encontrar-se na aproximação contínua somente sob esta condição. (KANT, 2010b, p. 41).

Desse modo, fica evidente que Kant acredita na possibilidade de se chegar à paz mundial, à paz perpétua, apenas pela constituição de um organismo internacional que tenha como intenção "regular" as relações entre os Estados e garantir a liberdade e hospitalidade aos indivíduos em escala mundial. O direito cosmopolita em Kant é condição de possibilidade para a construção dessa organização que o autor nomeia de federação de Estados livres e à constitui como condição e possibilidade para se atingir uma situação de paz mundial entre os estados e entre os indivíduos.

Nesse seguimento, o projeto cosmopolita kantiano tem como principal intenção e objetivo central a realização do destino da humanidade, e por isso se pensar o cosmopolitismo, ou, um/o arranjo cosmopolita da sociedade mundial como uma "comunidade de destino" para a humanidade. Para tanto, é necessário que o homem desenvolva e cultive a sua razão afim de sempre progredir enquanto ser humano, ligando o progresso da condição humana ao desenvolvimento da razão por parte do ser humano, o que levaria a espécie necessariamente a unir-se em um sistema cosmopolita e buscar a fundação de uma "condição cosmopolita universal" para a convivência humana e o desenvolvimento da humanidade centrado nessa "comunidade de destino".

De acordo com Alonso (2002), no projeto pensado por Immanuel Kant é perfeitamente possível compatibilizar os fins intencionados por cada indivíduo com a construção de uma comunidade universal de destino para a humanidade. Os direitos sejam numa perspectiva individual ou comunitária, podem ser compatibilizados de modo que a realização individual do direito de cada ser humano não implique a impossibilidade de se pensar a humanidade enquanto uma comunidade universal. Como aponta Goyard-Fabre (2006) mesmo em meio às dificuldades naturais que permeiam a insociável sociabilidade é possível caminhar rumo a um horizonte de sociabilidade mundial em que a humanidade e sua preservação sob uma perspectiva global sejam o principal fundamento dessa ordem internacional. "O direito universal é arquitetonicamente estruturado por relações de finalidade que, claro, não tem validade objetiva $[\ldots][\ldots]$, mas que, longe de qualquer banalidade realista, possuem um significado transcendental”. (GOYARD-FABRE, 2006, p. 199)7

\footnotetext{
${ }^{7}$ Quando os povos e os indivíduos abrem mão de parte de sua soberania e autonomia, em direção a uma "condição geral" de livre arbítrio indo de encontro ao mesmo fim, o direito - tanto nacional, quanto internacionalmente deixa o estado de irracionalidade ao qual se encontrava e ruma para a proposição de uma comunidade jurídica universal que se coloca com e à serviço da humanidade e do alcance da paz perpétua. (ALONSO, 2002). Kant (2013, p. 199) é claro ao determinar que a "ideia racional de uma comunidade pacífica perpétua de todos os povos da terra (mesmo quando não sejam amigos), entre os quais podem ser estabelecidas relações, não é um princípio filantrópico (moral), mas um princípio de direito", ou seja, o cosmopolitismo é um projeto que para além de simples regulação aparente, deve ser posta como um direito que para além da idealização utópica, vincula a prática internacional dos povos/dos Estados em direção à consolidação da paz perpétua mundial.
} 
De acordo com Kant (2013), os princípios políticos que conduzem os homens e os povos em direção à condição de paz perpétua que devem atingir enquanto dotados de razão e em progresso de sua condição humana, são perfeitamente compatíveis e alcançáveis com o desenvolvimento do direito e a possibilidade de uma juridicidade comum que se consolida a partir de uma prática legal desses princípios enquanto direito racionalmente concebido. Segundo Goyard-Fabre (2006) esses princípios reguladores da razão que fundamentam o projeto cosmopolita kantiano fazem com que o seu cosmopolitismo seja mais do que simples "sistemas de papel" e possa ser fundamentalmente um caminho para o direito internacional e para a busca da paz mundial. "A idealidade transcendental desse "princípio de reflexão" é o guia de uma escrita em que, contra os "falsos profetas", preparase o nascimento do "direito cosmopolítico". (GOYARD-FABRE, 2006, p. 200). Mesmo que ainda partindo de Goyard-Fabre (2006) possa parecer, ou, até mesmo ser uma realização tardia, e em certa medida irrealizável de maneira duradoura, ainda assim, aparenta uma esperança no que toca à desordem do mundo e das relações internacionais entre Estados.

Nesse plano, o direito cosmopolita tem em Kant como espaço privilegiado o globo terrestre, a Terra como espacialidade de todo e qualquer ser humano que tem direito de estar e sobre a Terra. O cosmopolitismo kantiano vislumbra o globo terrestre sob uma perspectiva horizontal que constitui um ambiente de interrelação entre os seres humanos e possibilita um constante contato entre os homens e suas culturas, fazendo progredir a humanidade rumo à um aculturamento tal que implica a percepção de uma condição de igualdade e liberdade entre todos no mundo. (KANT, 2010b).

Por isso mesmo, kantianamente, o direito cosmopolitíco é um direito interestatal e não supraestatal: há uma relação horizontal entre os Estados e os indivíduos que, em escala mundial, se relacionam nessa "comunidade de destino", que é a humanidade sob o ponto de vista cosmopolita. Estabelece-se necessariamente com o pensamento kantiano o direito cosmopolitíco como pertencente à ordem pública que permite pensar-se conjuntamente na obrigatoriedade por um jus cogens que obriga os homens de maneira jurídica constituindo um direito internacional que compreende Estados e indivíduos em constante relação. (GOYARD-FABRE, 2006).

Nessa sequência, o direito cosmopolita então é um direito de visitação, bem como um direito à hospitalidade universal e à construção de um ambiente de paz mundial entre os povos que corresponde a uma organização política republicana em caráter mundial, contemplando o direito cosmopolita como um direito vinculativo e não como mera utopia a ser buscada, mas nunca alcançada. (NASCIMENTO, 2011). A união de povos kantiana ou federação de Estados livres que proposta pelo autor ganha corpo como uma possibilidade latente e destino natural a partir do republicanismo como princípio máximo de organização política dos Estados, que abandonam o 
estado de natureza e orientam-se pela busca da paz mundial é a consolidação do direito cosmopolita. Segundo Nour (2013), a partir dessa construção, Kant critica as práticas colonialistas dos Estados europeus quando tratam eufemisticamente a conquista de outros povos como uma "visita", e, no entanto, em verdade, estão a conquistar e verdadeiramente anular o outro o desconsiderando em sua humanidade por ser diferente.

Porquanto, embora Kant (2010b) efetivamente critique os processos colonizadores da América, África e Ásia, bem como o tratamento dispensado aos nativos americanos e aos negros africanos, em certa medida o seu projeto cosmopolita não parece para o autor da presente tese alcançar tais povos, pois, assentado em uma perspectiva racional e estatal que vislumbra em dada organização política pela forma do Estado e do republicanismo as Nações que devem ser atendidas por esse projeto kantiano. O cosmopolitismo kantiano tem limites e a sua federação de Estados livres ou união de povos assenta-se em pressupostos estritamente racionais e moderno-europeus, o que desde a sua época até a contemporaneidade o limita enquanto um projeto universal.

No entanto, o desenvolvimento dessa federação de Estados livres, ou união de povos, como pregado por Immanuel Kant, encontrou e encontra limites, sobretudo, na contemporaneidade e no estado de guerra global que se passa. Nesse sentido, o cosmopolitismo kantiano foi criticado, defendido, e, até mesmo, passou por um processo de evolução a partir da construção teórica de determinados autores, entre os quais, pode ser citado como mais importante e fiel discípulo o alemão Otfried Höffe, e é o que se passa a tratar.

\section{AINDA POR UM PROJETO COSMOPOLITA E A REPÚBLICA MUNDIAL DE HÖFFE}

De acordo com Grossmann (2006) Höffe constrói sua teorização partindo do pressuposto de que Kant tivesse dado continuidade à sua comparação entre indivíduos e Estados no que tange à saída do estado de natureza, e ele teria chegado à possibilidade de constituir-se um Estado de povos ao invés de uma aliança de povos ou federação de Estados livres. Nesse sentido, mantém-se os pressupostos kantianos para a obtenção da paz perpétua entre os Estados, mas se avança em direção a um "contrato cosmopolita" que se mostra mais vinculante na obra de Otfried Höffe.

Com efeito, os Estados, embora, possam ser analogamente comparados aos indivíduos, evidentemente não tem todos os direitos que aqueles, pois, sujeitos coletivos, que devem sim, obrigatoriamente para ser considerados como membros de uma comunidade de destino estar de acordo com os direitos humanos. Os direitos humanos devem necessariamente ser respeitados por qualquer estado para que esse possa ser considerado legitimamente como ente político-jurídico, ou seja, quando há um grau de injustiça por demais elevado no que tange ás práticas de algum Estado 
se torna inviável conferir-lhe legitimidade na esfera internacional. (GROSSMANN, 2006). Com Höffe (2005) é inquestionável que se necessita de uma agenda global, e, que se tem problemas que podem ser tratados em escala global, bem como, é necessário que se perceba em quais campos é preciso que se pense em um plano de atuação global, e, nesse sentido, é indispensável pensar um Estado Mundial/Global que seja capaz de constituir-se como centro de poder no que toca à resolução dessas questões.

Evidentemente não se parte do princípio de dissolução dos Estados, como fica bastante claro nas formulações postas até agora, o autor, em verdade, é no sentido de complementariedade que surge a República Mundial ou Estado Mundial höffeniano. Os Estados por terem alcançado em sua maioria parâmetros adequados em relação á promoção dos direitos humanos seguem sendo atores importantes, até porque, constitutivos da República Mundial que, é, e não se pode esquecer uma república federativa e subsidiária de Estados. (HÖFFE, 2003a). Nesse plano, os Estados nacionais permanecem com sendo responsáveis pela garantia jurídica em primeira instancia, dos direitos humanos, tendo sim uma responsabilidade e um dever para com a concretização da paz mundial, sendo o Estado Mundial um Estado complementar, de acordo com o próprio princípio da subsidiariedade. $\left(\right.$ HÖFFE, 2005) ${ }^{8}$.

Dessa forma, é rechaçada de maneira bastante evidente pelo autor alemão qualquer possibilidade de, a partir da República Mundial ou do Estado Mundial se dar forma a um verdadeiro Leviatã global. É justamente para evitar tal possibilidade que a República Mundial é federal e subsidiária, não centralizando poderes e nem sendo autoritária, até porque, na esteira dos Estados individuais - em sua maioria - regida pela democracia e pelos direitos humanos, e na direção de ambos. A República Mundial não se fundamenta de cima para baixo, mas sim, de baixo para cima, pois, eminentemente democrática, compromissada com os interesses primeiros dos Estados individuais e dos cidadãos no que concerne aos direitos humanos. (HÖFFE, 2005).

Nessa caminhada, os direitos humanos tem um conteúdo moral e um conteúdo jurídico, sendo exigências jurídico-morais que fazem com que qualquer Estado que os desconsiderar, enquanto prática e conteúdo, perca a sua legitimidade. De outra banda, os direitos humanos são prévios, anteriores ao contrato social, à formação da estatalidade, eles são direitos intrinsecamente ligados aos homens, que deverão reciproca e compartilhadamente garantir-lhes a proteção e

\footnotetext{
${ }^{8}$ Höffe, e que isso fique bastante claro, não defende em momento algum a criação de um Estado Mundial centralizador do poder, nem dos deveres de direito e justiça ocupando posição superior em relação aos demais Estados, ou, em relação á toda a ordem internacional posta até o momento na história da humanidade. Não há espaço na teorização do autor sobre um direito cosmopolita para a construção de uma estrutura de poder centralizadora e autoritária que se sobreponha aos entes estatais que a conformam de maneira a sobrepujar os poderes e deveres da estatlidade com os seres humanos - seus cidadãos ou não - e para com os próprios direitos humanos.
} 
concretização de tais direitos. (HÖFFE, 2005). Ainda com Höffe (2005) não é possível pensar e conceber um poder legitimamente democrático que não respeite os direitos humanos e a(s) humanidade(s) para além dos seus próprios cidadãos, devendo embasar toda a sua prática estatal num parâmetro indistinto de proteção e concretização doa direitos humanos que se coadune com a busca por um destino comum para a humanidade.

Pode-se dizer que os direitos humanos são anteriores ao contrato social, ou seja, ao próprio estatalismo, e configuram um conteúdo transcendental em relação às institucionalidades jurídicas e políticas criadas pelo homem para gerir a vida em sociedade. O caminho para os direitos humanos como um fundamento universal de validade de toda e qualquer organização politica, jurídica ou social, é intrinsecamente condição e possibilidade para que seja constituído qualquer projeto de cosmopolitismo para albergar a humanidade sob um mesmo patamar indistinto de proteção e concretização desses direitos. Claro que o próprio Höffe (2003a) deixa claro que já há um patamar de proteção e concretização dos direitos humanos na esfera dos Estados nacionais (individuais), haja visto, em sua maioria encontrarem-se sobre a égide de regimes democráticos e adstritos ao modelo liberal e social de democracia, assim sendo, comprometida com os direitos humanos.

Para Höffe (2003b) os direitos humanos são direitos devidos a todo e qualquer membro da comunidade jurídica, não decorrendo necessariamente de um favor social ou político, dessa forma, não se ligando necessariamente á pretensões destinadas ao Estado, embora, evidentemente caiba á ordem estatal garantir esses direitos aos cidadãos e a toda e qualquer pessoa. Os direitos humanos aparecem na teoria cosmopolita do autor como condições universais para o ser/estar-no-mundo, sendo por isso necessário se pensar um direito que perpasse os limites da estatalidade o que o autor faz a partir do cosmopolitismo.

Para tanto, é necessário que haja por parte dos Estados uma determinada cessão de poderes em favor de um bem maior, ou seja, os entes estatais devem em certa medida abrir mão de parte de sua soberania em nome da constituição dessa confederação de Estados/de povos, pois, dessa maneira é possível que se constitua uma ordem mundial que se coloca para além das estruturas estatais e pode, em relação aos direitos humanos, por exemplo, impor condutas e, até mesmo, coercitivamente penalizações pelo descumprimento no que tange aos conteúdos dos direitos humanos. "Somente quando os Estados tiverem concordado em se submeter a um desejo geral, o que exigirá voluntária e gradativa renúncia da soberania, haverá o alcance pleno da paz”. (HÖFFE, 2005, p. 117).

É dentro dessa perspectiva que o autor refere a necessidade de se organizar uma estrutura operacional que para além dos Estados consiga organizar esses âmbitos de concorrência que no mais das vezes geram desigualdades entre os povos. É necessário que se institua uma ordem jurídica 


\section{Quaestio Iuris}

vol.12, nº.04, Riode Janeiro, 2019.pp. 608645

DOI: $10.12957 /$ rqi.2020.43358

mundial e uma organização democrática para essa ordem jurídica, o que Höffe vai tratar por uma democracia mundial, que deve organizar-se de forma republicana e estar comprometida com a garantia e concretização dos direitos humanos em escala global e com a divisão dos poderes. (HÖFFE, 2003a). E segue Höffe (2003a), na direção de que por mais que haja a necessidade de se esquematizar uma ação global e de se constituir uma institucionalidade jurídico-política mundial, e o Estado isoladamente considerado, bem como, os blocos continentais como a União Europeia fiquem relativizados, eles não deixam de existir, nem perdem força, nem abrem totalmente mão de sua soberania, pois, segue-se um princípio de manutenção do Estado em suas potencialidades, em que pese o novo arranjo global/mundial.

A questão que se coloca aqui, é que na construção teórica höffeniana não há que se pensar no fim do Estado, das organizações internacionais, das organizações não-governamentais, ou, de qualquer ator que componha a ordem internacional contemporânea, mas sim, há uma reestruturação que coloca a ordem internacional a partir da constituição de uma República Mundial, ou, de um Estado Mundial, que representa interesses comuns da humanidade para além dos já compreendidos dentro do raio de atuação de todo e qualquer Estado. De acordo com Grossmann (2006) Höffe é bastante claro e impositivo no sentido de que não se pode pensar para a consecução da paz mundial, nada menos do que um Estado Mundial, pois, restaria a insegurança de não se estar sob um estatuto jurídico, em optando-se pela federação de Estados livres ou união de povos kantiana.

O autor alemão vislumbra um "Estado de Estados", o que implica uma não extinção do aparato estatal, pois, o cosmopolitismo höffeniano se mantém ligado à estatalidade como parte do projeto cosmopolita para a paz mundial. Nesse caso, há um componente de subsidiariedade na construção do Estado Mundial para o autor, bem como, ele seria secundário e complementar, compondo-se por Estados que se orientassem pelo republicanismo, pela democracia e pela garantia e concretização dos direitos humanos. (GROSSMANN, 2006). "Höffe sugere uma alternativa intermediária, baseada nos princípios da justiça - direito, poderes públicos, democracia e direitos humanos -, que é a criação de um Estado Mundial, federal e mínimo”. (GROSSMANN, 2006, p. $119)^{9}$.

\footnotetext{
${ }^{9}$ Nesse momento, justamente na intenção de limitar em certo sentido a constituição e os poderes de Estado Mundial, Höffe apresenta três vetos construtivos em que o primeiro, justamente se coloca contra a possibilidade de se criar um Estado unitário global, devendo-se em consonância com o federalismo e o republicanismo instituirse um Estado Federal Mundial. Para o autor alemão, a República Mundial é ou dever(i)á ser um Estado federal de muitos povos, enquanto cidadãos de um mesmo Estado nacional. Nesse ponto, é importante frisar que o autor não abre mão da existência e da importância dos Estados no cenário internacional, pois, são importantes atores - ainda hoje os principais atores - do direito internacional sendo suas principais normas decorrentes de tratados entre Estados, ainda, estão os Estados a fundar uma séria de organizações internacionais de fundamental importância no cenário mundial/global, bem como, são na sua maioria Estados comprometidos com os direitos humanos e a soberania popular. (HÖFFE, 2005). O segundo veto construtivo, faz oposição à constituição da República Federal Mundial à um só ato repentino e contínuo, que constituísse de imediato essa nova estrutura de poder na esfera internacional - no cenário mundial/global -, seguindo assim o "princípio da fase provisória", no sentido de que
} 
Desse modo, coloca-se o Estado Mundial höffeniano no meio do caminho entre um império universal e estatal que se torna dominante e homogêneo e um estado universal ultramínimo, o que impede que se imponha uma forma organizativa mundial que rejeite e ameace a integridade social e cultural de determinadas comunidades jurídico-políticas existentes, bem como, que se esvazie a sua capacidade jurídico-política em direção a um estado federal mínimo que não consegue se colocar como um ator internacional e "por ordem" no estado de natureza internacional que se agiganta na atualidade. (HÖFFE, 2003b).

Portanto, a República Mundial federal e subsidiária se conforma na perspectiva de um aumento conteudístico e de esfera protetiva dos direitos humanos sob um princípio universal de justiça que faz com que seja possível subsidiariamente constituir-se um nível de proteção e concretização dos direitos humanos que trabalha para além das instituições estatais, sem ás retirar legitimidade e competência. É possível dizer com Höffe (2006) que os direitos humanos são um ponto central em toda a formulação teórica höffeniana, pois, assumem condição de possibilidade para legitimar todo e qualquer regime democrático, já que o autor vislumbra a democracia como o regime privilegiado para a execução dos conteúdos de direitos humanos.

Nesse ponto, é verificável a necessidade de se constituir uma justiça mundial, sobretudo, no que tange aos crimes contra a humanidade em que seja na orbita nacional ou internacional, seja pelas ações do Estado ou do Estado Mundial, devam ser punidos de acordo com as cartas políticas e tratados internacionais, bem como, no que se vislumbra como um direito cosmopolítico que tenha os direitos humanos como fim maior. Os direitos humanos assim devem se assegurados a todos os seres humanos em qualquer lugar do mundo, e isso implica um direito de cidadania mundial que não elimina a cidadania nacional, mas à complementa alargando o campo de ação da cidadania que deixa de estar necessariamente vinculada ao pertencimento à algum lugar que não o mundo. (HÖFFE, 2003b).

Dessa forma, conformar um sistema de justiça universal é um princípio também de legalidade e não apenas deve ser uma intenção política, para além de um vínculo moral sempre

este novo ator internacional seria instituído aos poucos tendo níveis inferiores de organização do mesmo como estruturas organizacionais e procedimentais. A nova ordem mundial hierarquiza-se a partir de 1) Estados nacionais; 2) organizações internacionais; 3a) a República Mundial que se instituiria num primeiro momento como uma Confederação Mundial de Estados; e 3b) o Estado Federal Mundial que assumiria o papel da confederação num primeiro momento. (HÖFFE, 2005). No terceiro veto construtivo, o autor apresenta o princípio da subsidiariedade que faz com o que já é conteúdo de tratamento pelos Estados siga sendo de sua responsabilidade, passando á habitar o raio de ação da República Mundial as questões em que a atuação sozinha dos Estados não se basta, ou seja, em problemáticas eminentemente globais que necessitam de um novo tratamento por parte do direito e da política. (HÖFFE, 2005). Essa formulação höffeniana alude que a República Mundial não parte de uma premissa homogeneizante e evidencia ser totalmente possível constituir uma República Mundial como um "andar superior" no que tange ao tratamento da humanidade e a garantia e concretização dos direitos humanos em uma perspectiva mundial/global. "As democracias nacionais somente precisam abrir espaço para uma República Mundial quando fracassa sua capacidade de proteção ao direito e à justiça”. (HÖFFE, 2005, p. 345). 
existente entre a obrigatoriedade de se dar forma a qualquer instituição de garantia para os direitos humanos e esses próprios direito - e a humanidade - passa a haver um vínculo legal que impele que os Estados em escala mundial constituam um sistema de justiça universalmente protetivo para os direitos humanos em suas mais variadas manifestações. Nessa perspectiva Höffe (2005) cumula de maneira impositiva - jamais autoritária - a necessidade vital de se instituir efetivamente uma justiça mundial, dando inclusive forma à essa nova estrutura jurídica global que ocuparia um lugar importante e de destaque no cenário mundial. "São necessários tribunais ou cortes internacionais com competência internacional, visando a dirimir litígios em suas duas formas básicas, tanto no campo do Direito Civil quanto no campo do Direito Cosmopolítico". (HÖFFE, 2005, p. 428).

Segue o autor, referindo que se deve instituir tribunais internacionais que passariam a ter por função dirimir conflitos entre os Estados, e, entre os Estados e a República Mundial, enquanto, ficaria sob competência dos tribunais de Direito Cosmopolítico os conflitos que envolvessem atos ilícitos cometidos contra os indivíduos ou grupos de indivíduos, como atos de discriminação contra a mulher, ou de discriminação racial, ou contra os estrangeiros. (HÖFFE, 2005). É importante a colocação de Höffe sobre o dever de se pensar um sistema de justiça que não seja seletivo quantos aos crimes contra a humanidade que devem ser punidos - todo e qualquer crime contra a humanidade deve ser punido -, nem contra qual a humanidade que é vítima de crimes, bem como, é imprescindível que se pensa essa justiça mundial sob uma perspectiva de não esquecimento e não seletividade de crimes, humanidades e agentes. (HÖFFE, 2003b).

Nessa formulação de cosmopolitismo é necessário que para além dessas cortes e tribunais internacionais e cosmopolitas, haja efetivamente um "senso do/de direito mundial", ou, um "senso comum de justiça" que seja mundialmente compartilhado pelos Estados entre si e pelos Estados e a República Mundial. Os cidadãos de cada estado individualmente, que, a partir da fundação da República Mundial tornam-se verdadeiramente também cidadãos do mundo, devem ser orientados por princípios comuns de justiça e direito que saem do "mero" dever moral de cumprimento, para um dever legal universal de cumprimento assentado nesse "senso de/do direito mundial". (HÖFFE, 2003b).

De acordo com Saldanha (2018), a cidadania cosmopolita confere ao ser humano uma condição de estar no mundo como um cidadão do mundo que é o cosmopolita na atualidade, fazendo parte de uma ordem jurídica mundial, mas, sobretudo, sendo parte da humanidade como uma "comunidade de destino" que a partir do cosmopolitismo se possibilita como instituição normativa e não apenas filantrópica ou dever moral. Há um dever de justiça na proteção da pessoa humana que não se manifesta mais somente nas delimitações estatais, mas sim, implica uma condição de 
mundo que seja condição de humanidade para os seres humanos em qualquer parte do mundo. Por conseguinte:

\begin{abstract}
Considere-se cidadão mundial ou cosmopolita aquele que não se atém às fronteiras, que se desloca por todo o mundo, porém que se sente - mais ou menos - em casa por todas as partes por onde anda. Na medida em que conserva sua língua, sua cultura e seus costumes, mas se deixa levar pela língua franca (antigamente era o grego, hoje em dia é o inglês), não passa de um cosmopolita de primeiro grau: viajante mundial, que, mesmo no estrangeiro, não abre mão de seus vínculos locais e nacionais. Só virá a ser um cidadão mundial mais sofisticado, um cosmopolita de segundo grau, se alcançar aquela abertura para o mundo que o faça perceber o estrangeiro, reconhecendo-o com igualdade de valor. Em um sentido mais intenso, cidadão mundial é aquele que leva sua própria cultura a um outro país, mas se deixa marcar pela nova cultura e não abdica das novas características após o retorno a sua terra natal. (HÖFFE, 2005, p. 394).
\end{abstract}

Assim, delimita-se e determina-se a figura do cidadão do mundo, de um cidadão mundial que se mostra e coloca em ação para além do pacto social originário, embora, permanecendo evidentemente ligado a esse. O cidadão do mundo é o cosmopolita contemporâneo, ele não se limita às fronteiras ou ás estatalidades, mas sim, ele se constitui em todo e qualquer lugar e constitui direitos que para além da sua condição de cidadão estão ligados á sua condição de ser humano. Se torna necessário e possível vislumbrar uma cidadania mundial que extrapola os limites do EstadoNação, dos modelos de justiça existentes, e, sobretudo, do paradigma de direitos humanos construído pela modernidade europeia e consolidado mundialmente até a atualidade.

O cosmopolitismo como percebido a partir de Höffe necessita de uma cidadania mundial que corrobora com um ideal cosmopolita de indicação do ser humano, do cidadão mundial como um parâmetro para o desenvolvimento da República Mundial. Pela leitura de Höffe (2003a) o cosmopolitismo congrega uma dupla população que se concretiza enquanto cidadão do Estado e cidadão do mundo, que tem lugar tanto nacional, quanto internacionalmente, isso, porque é cosmopolita por excelência. $\mathrm{O}$ cosmopolitismo que se assente em princípios de justiça e humanidade, é um cosmopolitismo para além de republicado e federativo, como também, democrático, um cosmopolitismo humanista centrado no cidadão, na pessoa humana e na sua condição de ser humano para fora dos limites geográficos que encerram a cidadania estatalmoderna.

Desta perspectiva funda-se uma cidadania intercultural que se constrói assentada em padrões comuns acerca dos direitos humanos e das condições de humanidade que se colocam como fundadoras de uma humanidade universal e que se pretende comum, mundial. Os princípios de justiça que fundamentam a República Mundial implicam que os seres humanos sejam considerados 
mundialmente como cidadãos de um meio intercultural que lhes "origina" como cidadãos mundiais, cidadãos do mundo - na dupla perspectiva já mencionada - como pertencentes a um ambiente comum, há um mesmo cosmopolitismo. (HÖFFE, 2008). De acordo com Grossmann (2006) é possível que se note um direito à diferença dentro da República Mundial, que permite aos indivíduos - destinatários originários desse direito - e aos Estados moverem-se um uma margem de deslocamentos que possibilita o vir-a-fala de suas características individuais. O que coloca a República Mundial sob um ponto de vista de conservação e luta pela coexistência pacífica, plural e compartilhada das diversas humanidades que cosmopolitamente habitam o mundo.

Nesse viés, é importante e imprescindível que cidadania estatal/nacional e cidadania mundial/global dialoguem tendo como princípio reitor a interculturalidade que é condição de possibilidade para um verdadeiro cosmopolitismo, ou, para uma verdadeira República Mundial Cosmopolita que funde o homem, antes de como cidadão estatal, como cidadão mundial, e principalmente como sujeito de direitos - dos direitos humanos. (HÖFFE, 2008). Conforme Saldanha (2018) há um caminho sendo caminhado em direção a um reconhecimento planetáriouniversal das identidades - ou das singularidades - que é uma perspectiva de que cada vez mais o mundo se dirige para uma condição e cidadania mundial-universal que consolida os direitos humanos como vetores universais e parâmetros mundiais de e para a humanidade.

Não se pode ter dúvida aqui, de que o cosmopolitismo defendido por Höffe é sim um cosmopolitismo dos seres humanos, dos direitos humanos, e que tem uma perspectiva universal, mas, intercultural que o funda como um fenômeno/ambiente de respeito e solidariedade entre os povos, entre os Estados e entre os indivíduos. O mosaico composto por Höffe a partir de seu Estado Mundial federativo e subsidiário, que republicanamente se concretiza como uma República Mundial é o mosaico da diferença, mas do que há de comum entre os seres humanos, que é a direção no rumo de uma "comunidade de destino" que tem como horizonte constitutivo o cosmopolitismo como princípio reitor, universal e comum.

A grande questão que se coloca, é, se em meio ao paradigma "imperial" e às suas institucionalidades, sobre tudo, no âmbito de um estado de exceção permanente que se institui como um estado de guerra global é possível ainda um projeto cosmopolita nos moldes kantianos ou höffenianos"? Ainda é possível o cosmopolitismo como um fenômeno ou ambiente que de conta dos conflitos por direitos, vividos contemporaneamente? O cosmopolitismo ainda pode se colocar como fundamento ético-moral-filosófico para uma institucionalidade que tenha capacidade de perpassar a era do "Império" e dos controles biopolíticos sobre a humanidade? É possível com o cosmopolitismo refundar os direitos humanos de maneira verdadeiramente intercultural, perpassando os seus fundamentos moderno-euro-ocidentais hegemônicos e diferenciadores da 
espécie humana? Ainda, é o projeto cosmopolita na atualidade o lugar para os direitos humanos em perspectiva global, sobretudo, frente aos movimentos do modelo político-econômico capitalista e dos comandos neoliberais do mercado?

Essas questões que são postas ao fim desse subcapítulo pretendem-se respondidas no caminho desse trabalho, ficando claro que o cosmopolitismo, ou, pelo menos, os projetos cosmopolitas teorizados - e postos em prática - até hoje, não deram e não dão mais conta da complexidade que envolve as relações jurídicas, políticas e sociais que circundam a humanidade na atualidade. Nessa perspectiva, demarca-se qual o lugar dos direitos humanos e do cosmopolitismo em meio ao estado de guerra global que orienta o paradigma de soberania contemporâneo, e, é o que se passa a fazer.

\section{O "COMUMPOLITISMO" COMO UM NOVO AMBIENTE PARA OS DIREITOS HUMANOS}

Nesse percurso, o "comum" como um novo sujeito de direitos e dos direitos humanos enquanto o nome da "multidão", exige um novo lugar para esse(s) sujeito(s) que transborde os limites do estatalismo, e que de dentro do "Império" provoque a sua ruptura enquanto um lugar de exclusão e dominação. Os direitos humanos demandam por uma nova localidade espaço-temporal que de maneira desinstitucionalizada considere a "multidão do comum" como um novo sujeito que provoca o desassossego e a desmesura das instituições postas pela modernidade e recriadas na pósmodernidade.

O Estado não comporta o "comum" como um sujeito plural, antagônico e revolucionário, tampouco, o "Império" que pretende controlar a "multidão" desarticulando a sua força e seus afetos e neutralizando o seu movimento em busca da ruptura e do tensionamento constante das estruturas “imperiais”. Nesse caminho, as possiblidades e alternativas pensadas ao longo da história estão sempre adstritas à essas formas institucionalizadas, seja ao Estado na modernidade, seja ao "Império" na contemporaneidade, o que, importa a criação de alternativas inseridas na mesma lógica de produção de sentidos e na mesma sistemática no que tange à produção e aplicação do Direito. (HARDT; NEGRI, 2014a).

Nesse sentido, os direitos humanos são sempre conduzidos por políticas institucionais sem nunca colocar em cheque as formas clássicas ou contemporâneas que regulam tais direitos sob uma ótica dominante e hegemônica, tanto no que tange aos lugares de proteção, quanto no que tange ao modo de proteger tais direitos, bem como, no que toca ao conteúdo e aos sujeitos desses direitos. Tais direitos, estão sempre inseridos na institucionalidade que, no mais das vezes para além de 
protegê-los - ainda que, com limitações teóricas, práticas, conteudísticas e estruturais -, viola-os de maneira indiscriminada. Não há espaço no contexto dessas instituições para um discurso diferente e alternativo sobre direitos humanos, como também não espaço para sujeitos que destoam da figura moderno-europeia-ocidental traçada como sujeito dos direitos humanos. (BRAGATO, 2016).

Essa crítica evidentemente deve se estender a algumas formulações que desde a modernidade aparecem de maneira igual ou reinventadas como possibilidade para repensar o lugar dos direitos humanos (um lugar para os direitos humanos) que para além da forma estatal de conta de uma complexidade que se intensifica e, desnaturaliza os locais classicamente pensados para a proteção e concretização desses direitos. É nessa perspectiva que as teorias engendradas em torno ao cosmopolitismo desde a modernidade, e, sobretudo, desde o pensamento kantiano, embora, possa ser dona de boas intenções, na conjuntura atual se mostra no mínimo insuficiente para promover os direitos humanos não só, para além dos limites do Estado, mas, principalmente, no interior do "Império" que enquanto paradigma de soberania contemporâneo tanto os coloca em cheque, ou, os utiliza de maneira a fundamentar suas práticas hegemônicas e dominantes.

Nesse caminhar, o cosmopolitismo, ou os cosmopolitismos que se arvoram a favor da humanidade, estão, ainda, a favor de determinada humanidade que é determinada por caracteres bastante específicos acerca do que é humano e do que pode ser considerado ou não um ideal cosmopolita para toda a humanidade. Geralmente, o ideal cosmopolita é o ideal da globalização e nesse passo é o ideal do "Império", que provoca um distúrbio no "estar-em-comum" e um deslocamento da problemática econômica do mercado, para o campo do social e dos direitos humanos com algo correlato. A globalização neoliberal é o estopim dos movimentos cosmopolitas globais, e temos da mesma forma que tivemos a modernidade um projeto dominando e hegemônico de expansão euro-ocidental e desconsideração dos que estão de fora desses limites bastante estritos da humanidade euro-ocidental.

Por isso, Hardt e Negri (2002) visualizam o movimento da "multidão" como algo que se dá no espaço mundial enquanto espaço constituinte e não limitado entre local e global. O movimento da multitudo é o movimento do nomadismo e da miscigenação que surgem de acordo com os autores como práticas éticas dentro do contesto "imperial". A multidão irrompe os limites estatais e "imperiais" rumo à constituição comum vislumbrando no "estar-em-comum" como luta e resistência à prisão da identidade, da Nação, do povo, da cidadania ou de qualquer caracterização (pós-)moderna e institucionalizada das subjetividades. Ainda com Hardt e Negri (2002) não há que se pensar o cosmopolitismo na trilha das trocas do local pelo global, concebendo essa relação como uma impossibilidade e como irrealização. Local e global se relacionam nos movimentos aberto pela 
(e da) "multidão" e (re)conformam o universal como verdadeiramente universal nos caminhos abertos pela movimentação multitudinária dos sujeitos.

Nesse momento, "fora de toda a nuvem de iluminismo ou de todo o devaneio kantiano, o desejo da multidão não é um estado cosmopolita mais uma espécie universal. Como um pentecostes secular, os corpos são misturados e os nômades falam uma língua comum". (HARDT; NEGRI, 2002, p. 384). Nesse seguir, a "ontologia comum" ou o "comum" ontologicamente compreendido é a constante produção e reconstrução do ser no movimento multitudinário dos corpos que singularmente realizam o trabalho vivo e pluralmente formam a "multidão. "A dimensão espacial de ontologia é hoje demonstrada pelos processos multitudinários concretos de globalização do desejo da sociedade humana - ou mais exatamente de torna-lo comum". (HARDT; NEGRI, 2002, p. 384).

Nesse plano, é importante citar o fim do terceiro mundo na lógica colonial e imperialista como um movimento de libertação a partir da libertação da multitudo que se movimenta promiscuamente além das fronteiras "imperiais" e contrasta o sedentarismo das potencias "imperiais" com o êxodo dos excluídos do Sul global. A "multidão" que se movimenta "emcomum" rompe com as definições globais e "imperiais" de sujeito, de espaço e de tempo, e constitui uma nova construção acerca da realidade que confunde local e global através da ação de um novo sujeito que "agindo-em-comum" agita as paisagens e abala as estruturas "imperiais". (HARDT; NEGRI, 2002).

Assim, se conforma biopoliticamente um novo movimento humano que compromete as instituições modernas e, sobretudo, desvela o projeto cosmopolita erguido por Kant e continuado por Höffe - para ficar apenas nesses - como um projeto limitado por uma concepção de humanidade - e aqui, sobretudo o projeto kantiano - que não possibilita o movimento plural e desordenado dos que "estão-em-comum". O projeto cosmopolita que esses autores representam, é um projeto que desfaz traços comuns e assombra determinados sujeitos com o estereotipo da exclusão e da não pertença a esse lugar representado pelo cosmopolitismo. O cosmopolitismo não se mostra verdadeiramente cosmopolita, no momento em que parte de referenciais específicos de humanidade que são construídos na modernidade e se expandem para além do mundo euro-ocidental.

Nesse movimento, Kant realiza uma articulação das categorias de tempo e espaço a partir do próprio homem como centro do mundo e do conhecimento validamente científico. Kantianamente considerados espaço e tempo pertencem ao homem e à sua racionalidade e possibilitam a construção de conhecimento - e direitos - enquanto verdades universais a partir de sua racionalidade inata à sua condição de homem racional. (GROSFOGUEL, 2008). Pode-se dizer com isso, que o cosmopolitismo kantiano organiza uma sistemática de pertencimento há um espaço- 
tempo substancialmente constituído intersubjetivamente na racionalidade do homem moderno, do sujeito da modernidade que entrega uma condição de ser-estar no mundo como ser universal, e que produz um conhecimento universalmente considerado válido e, ao mesmo tempo, é sujeito e agente de direitos universalmente considerados válidos e os únicos possíveis.

Nesse momento não há mais a luta do pobre e a do menos pobre, mas sim, há lutas de homens, mulheres, negros, asiáticos, indígenas, europeus, do sul e do norte global, de baixo pra cima e de cima pra baixo; lutas de resistência que produzem a vida a partir do antagonismo ás máquinas biopolíticas que produzem a morte, lutas da vida e pela vida, lutas de uma comunidade que se constitui "em-comum" como um nome próprio que nomeia a "multidão do comum" ou que dá o "nome comum" à multidão de singularidades que luta pela sua multiplicidade e pela sua pluralidade anti-imperial. Por essas condições de pertença que se fazem percebidas na "multidão" que constitui o "sujeito comum" - ou o "comum" como sujeito - é que o cosmopolitismo falha desde Kant até a contemporaneidade. O cosmopolitismo não se mostra como "em-comum", mas sim, como um projeto que não sendo excludente dentro da lógica que o conforma, o é, pois, contemplado por uma estrutura excludente estatal-“imperial” e estruturado sobre a diferenciação binomial de raça, credo, cor, sexo, lugar, espaço, tempo, ser, saber, poder, etc.

Nesse sentido, Hardt e Negri (2016) são claros em apontar a relação muitas vezes obscurecida entre modernidade e colonialidade que recoloca os dualismos de maneira real como um processo antagônico dentro da própria modernidade e que a constitui enquanto um paradigma que abarca dominação e resistência, soberania e lutas de libertação, incluído e excluído, civilizado e bárbaro, em um movimento antagônico de lutas que é compreendido e apagado pela própria modernidade como um traço inexistente de sua composição ${ }^{10}$. Nessa perspectiva, pode-se considerar o cosmopolitismo que surge na modernidade e se perpetua, mesmo que modificado até os dias atuais, sendo visto sobretudo, como uma possibilidade, ou, a principal possibilidade de se pensar, concretizar e garantir direitos humanos para além do paradigma estatal e contra a ação do "Império", como um fenômeno que recria essas distinções modernas que aniquilam as formas de vida concretas em nome da abstratividade de uma determinada humanidade que sempre se coloca como superior, seja no âmbito do Estado, do "Império" ou do próprio cosmopolitismo.

Os projetos cosmopolitas desde Kant até a atualidade, mantém e reproduzem a escala de humanidade e humanitarismo produzida pela modernidade como uma forma de sustentação do

\footnotetext{
10 "A categoria da colonialidade explica exatamente que sujeitos foram historicamente reputados irracionais e como foi possível a criação de um estereótipo de sujeito de direitos que se reflete na figura do homem branco, heterossexual, e cristão" (BRAGATO, 2016, p. 1818), em que todos os considerados diferentes que se afastam desse padrão de humanidade tem a sua condição humana negligenciada e desconsiderada e, ao invés de sujeitos dos direitos humanos, são sujeitos da violação desses direitos que os coloca na condição de subalternos e expropriados.
} 
"Império" sob as bases de um pretenso humanismo cosmopolita de que existe somente enquanto retórica, mas que não se materializa enquanto uma prática efetivamente humanitária ${ }^{11}$. Nesse caminho, se as forças da antimodernidade se encontram inseridas dentro da própria modernidade como nas lutas e resistências à dominação colonial, as lutas contra o "Império" estão inseridas na lógica e na estrutura "imperial" resistindo antagonicamente às práticas expropriatórias desse paradigma soberano, bem como, resistindo à colonialidade que se perpetua recriada sob a forma "imperial", mas, ainda produzindo diferenciações e com isso a subalternização de alguns em nome de outros. (HARDT; NEGRI, 2016) ${ }^{12}$.

Essa manutenção de práticas e discursos é que desabilita o cosmopolitismo como um fenômeno ou paradigma possível para assumir as lutas por direitos a partir do e contra o "Império", pois, acaba por reproduzir sua lógica de dominação e diferenciação que exclui e extermina as humanidades que se colocam como antagonistas desse processo de identificação e neutralização das diferenças. As singularidades não tem lugar dentro do cosmopolitismo, a não ser que sejam neutralizadas no interior de uma pretensa humanidade universal que se materializa como única possibilidade de atingir padrões ideais de direitos humanos e de sua concretização e garantia em âmbito nacional e internacional.

Desde o cosmopolitismo kantiano até os dias atuais, o cosmopolitismo é cosmopolita sob determinada ótica e a partir de um determinado critério na atribuição da condição de cidadão do mundo há sujeitos bastante específicos que detém condição humana suficiente para serem vistos como tal. Por isso, Hardt e Negri (2002) deixam claro que a multitudo não espera do cosmopolitismo sob as vestes de um Estado cosmopolita, de uma República Mundial cosmopolita, de um universalismo cosmopolita, de uma democracia cosmopolita mundial, ou, seja a partir de qual arranjo ou desenho possa se dar a esse projeto, a resposta ou a alternativa antagonista e revolucionária de resistência que ela necessita para se contrapor e perturbar cada vez mais o "Império".

Nesse seguir, os projetos cosmopolitas que se agigantam desde Kant até a contemporaneidade são nada mais que "cosmopolitismos de fachada", são um embuste cosmopolita que reproduzem a lógica estatal/"imperial" de produção de sentidos e de exclusão da diversidade,

\footnotetext{
11 "Cuando Kant propone su cosmopolitismo, se trata de un provincialismo europeo camuflado y vendido al resto del mundo como diseño global / imperial /universal" (GROSFOGUEL, 2008, p. 204), e isso implica nas trilhas abertas pelo universalismo não universal de Wallerstein - o universalismo europeu que intitula importante obra do autor já citada no presente trabalho - em um cosmopolitismo não cosmopolita.

${ }^{12}$ As sistemáticas de diferenciação racial, sexual, geográfica, racional, que constituíram a modernidade são mantidas e até mesmo tornadas mais agudas no interior do "Império". Isso se manifesta de maneira muito clara quando as práticas humanitárias descortinadas por grandes potências agindo em nome do "Império", e humanitariamente em nome dos direitos humanos - sempre de alguns humanos e sob certo ponto de vista do que seriam direitos humanos - sempre esquecem os que estão excluídos da lógica de produção do conteúdo e do discurso dos direitos humanos. (HARDT; NEGRI, 2016).
} 
do pluralismo, da diferença que é normalizada ou, em último caso eliminada no interior do Estado, e é dominada e exterminada no interior do "Império". Há um projeto cosmopolita "imperial" que se sustenta nas desigualdades produzidas pelo próprio paradigma soberano "imperial" e ao mesmo tempo legitima uma série de práticas que no plano internacional comprometem a instituição de um "projeto comum" arraigado nas singularidades que pluralmente se evidenciam no mundo como produtoras de significados que se distinguem das universalidades disseminadas pelo cosmopolitismo. O "Império" origina em suas dependências um cosmopolitismo que biopoliticamente permanece segregando e não se torna efetivamente cosmopolita, justamente porque "imperial" e, assim sendo, utilizado pelo biopoder imperial como mais um componente da máquina biopolitica que produz controle, exclusão e extermínio.

Não se pode ter dúvidas que se fala aqui de um cosmopolitismo epistemologicamente euroocidental-norte-americano que não considera cosmopolita ou cidadão do mundo o negro africano, o ameríndio, o latino-americano colonizado, o muçulmano, o asiático, a mulher, o homossexual, o transexual, o europeu pobre, o imigrante; que não considera cosmopolita as singularidades que classicamente são vistas como anormais, ou incivilizadas, ou, que mesmo no raio de atuação do Estado não tem seus direitos concretizados, garantidos e preservados. $\mathrm{O}$ cosmopolitismo que se crítica nesse trabalho é também um projeto dominante tanto quanto foi o Estado Moderno ou é o "Império" contemporaneamente, até porque, na atuação "imperial" ele é uma ferramenta para legitimar a atuação do paradigma de soberania atual, do nomos soberano atual na perpetração de violações contra os que não se encontram inseridos no cosmopolitismo que possibilita a proteção da humanidade em esfera global/mundial.

Dessa forma, os cosmopolitismos de Kant a Höffe conformam um modo-de-ser-no-mundo que é eminentemente moderno-europeu e ocidental e que preconiza os direitos humanos de forma excludente de uma série de direitos considerados menos humanos e de um sem fim de sujeitos considerados menos humanos. Kant mesmo com a busca pela paz perpétua como algo válido e totalmente legitimo, pensa o direito à visitação ou à hospitalidade pela lente do europeu, branco, varão e proprietário, ou seja, do sujeito superior que tem condições de propor um direito de visitação, pois, é ele que se lança ao mundo e se faz cidadão do mundo.

O racionalismo kantiano e sua morfologia antropologicamente construída sob as bases do humanismo moderno e, sendo responsável pela construção desse humanismo, por exemplo, a partir da formulação do conceito de dignidade que está relacionado à racionalidade humana, vincula o direito de visitação à condição racional do homem europeu no mundo, bem como, utiliza a figura do Estado moderno como instituição legitima para delimitar esse direito e colocar limites ao seu exercício. Nessa maré, o projeto kantiano é um projeto limitado de paz, pois, compreende enquanto 


\section{Quaestio Iuris}

vol.12, nº.04, Riode Janeiro, 2019.pp. 608645

DOI: $10.12957 /$ rqi.2020.43358

detentores e devidamente os sujeitos que devem desfrutar dessa paz, somente os europeus que civilizadamente conseguem a partir de sua racionalidade construir um programa de paz mundial considerando o mundo civilizado moderno-europeu ${ }^{13}$.

"Trata-se, portanto, de romper com o abismo criado pelo humanismo racionalista, que criou classes distintas de seres humanos, cuja relação tornou-se uma impossibilidade a não ser por meio de dominação e opressão". (BRAGATO, 2014, p. 224). No entanto, não é no interior do estatalismo, do cosmopolitismo ou do paradigma "imperial" enquanto institucionalidades que essa relação de dominação sofrerá a necessária ruptura, pois, não há nesses lugares um processo antagônico, revolucionário e de resistência às práticas que violam direitos e humanidades. ${ }^{14}$

Nesse contexto, os processos de luta que eclodiram de maneira antagonista e revolucionária por diversas partes do mundo nos anos 2000, seja, no 2011 da primavera árabe, seja nos movimentos dos indignados na Europa - Espanha, Grécia, Portugal, Itália - a movimentação em Seattle, Davos, os Foros Sociais Mundiais, são movimentos da "multidão do comum" que se manifesta em sua pluralidade singular - ou em sua singularidade plural - e pressiona o "Império" na busca por direitos humanos. Com Hardt e Negri (2014b) esses processos constituintes são modos de ser do "comum" e são um "estar-em-comum" que desalinha as práticas "imperiais" e desarticula as armas biopolíticas de controle, pois, a multitudo em suas singularidades selvagens desfaz-se do controle e da lógica de submissão do biopoder “imperial”. Os movimentos da multitudo são excessivamente constituintes de um novo sujeito que se apresenta como ruptura e possibilidade, como sujeito da

\footnotetext{
${ }^{13}$ Nesse caminhar o cosmopolitismo kantiano se mostra totalmente controverso quando defende na obra a Paz Perpétua a possibilidade de o direito de visitação ser rejeitado pelos povos ameríndios frente aos europeus quando tiveram suas culturas desrespeitadas. No entanto, a partir da antropologia kantiana os ameríndios não podem ser considerados seres racionais ou detentores de uma dignidade, e assim sendo, não fazem parte de seu projeto cosmopolita. Além do que esses povos não são adeptos da organização política posta pelo estatalismo como a única possível para o exercício da civilidade, pois, com Hobbes, fora do contrato social e da mediação do Estado a multidão selvagem é incontrolável e não possui direitos, pois, origina-se e constitui um ambiente de total anomia no que tange ao Direito e aos direitos.

14 Desse modo, os direitos humanos, seu discurso, seu conteúdo, seu sistema de proteção e sua universalidade não alcançam a todos os seres humanos do mundo de maneira indistinta. Em que pese os esforços internacionais para a consecução de um arcabouço protetivo internacional dos direitos humanos, principalmente no que tange à abordagem discriminatória sofrida por alguns sujeitos específicos, a trajetória rumo a um sistema internacional de proteção dos direitos humanos e das humanidades singularmente consideradas na sua multiplicidade é por demais pedregosa e marcada por um discurso segmentado de construção conteudistica dos direitos humanos e de percepção por parte da humanidade dos sujeitos de direitos que estão sendo ainda hoje deixados de fora da definição e da construção constante do que são os direitos humanos e de quem são os humanos desses direitos. Não há uma espacialidade e uma temporalidade que abarquem todos esses sujeitos de direitos que foram deixados de fora do Estado, do cosmopolitismo, do "Império", e que foram deixados sem direitos à margem do arcabouço jurídico-normativo construído para proteger os sujeitos das violações de direitos às quais estão a mercê. "É isso que explica a formação dos processos de vulnerabilidade que os direitos humanos têm que lidar e que é profundamente distinta entre os seres humanos" (BRAGATO, 2014, p. 224), que estão dispostos no tabuleiro do jogo "imperial" como peças que hierarquizadamente podem ser perdidas ou não. O ser humano que habita o Sul global, ou, o que vive na periferia europeia, ou, então, a mulher indígena, negra, e até mesmo europeia mas descendente de imigrantes, esse pode sofrer com o descarte, com a violação de direitos básicos que lhe constituem enquanto ser humano, enquanto sujeito na humanidade que deveria poder compartir.
} 
práxis que "em-comum" se articula frente ao "Império" e impõe a construção de um ambiente que abarque as lutas sem ser institucionalizado, de um "lugar-em-comum" que se movimenta pelo e com o "comum" e que movimenta o "comum" em direção à radicalização da democracia e dos direitos humanos no antagonismo e na resistência que geram o "comum" e que são gerados a partir do "comum".

A luta, a partir do "comum", ela é plural e compartilhada, ela é enquanto prática viva uma realização do "estar-em-comum" na articulação do trabalho vivo e na imposição de forças biopolíticas contra as estruturas clássicas e expropriatórias do capital, justamente, através do fenômeno do trabalho vivo, ou seja, o trabalho imaterial rompe com as práticas de dominação do capital que se transmuta em um aparato biopolítico de controle, mas que, assim mesmo, não consegue subsumir no real toda a força do trabalho vivo. (HARDT; NEGRI, 2014b). O trabalho vivo é eminentemente selvagem, revolucionário, expansivo, ele excede às instituições do capital e excede as instituições "imperiais", transbordando os limites da produção material e adentrando o terreno da produção social, numa circular de constante produção de subjetividades que enquanto novos sujeitos não estão subsumidos ao valor do capital, e, assim, podem revolucionariamente se colocar na arena de luta contra o sistema mundo - e pelos direitos humanos. (NEGRI, 2016b).

Desse modo, o cosmopolitismo kantiano em que pese não seja um projeto global ele também não consegue ser crítico ou verdadeiramente humanista, pois, ancorado nos pressupostos lançados pela modernidade/colonialidade. Nesse viés, também os cosmopolitismos que se seguem, seja pensando no projeto de república mundial desenhado por Höffe, na democracia global de David Held ou no cosmopolitismo social-democrata de Beck, seguem ligados aos pressupostos modernos e, em alguns casos, incorporam elementos da pós-modernidade "imperial".

Dessa maneira, se mostra claramente necessário e imprescindível se pensar um ambiente para os direitos humanos em uma perspectiva internacional de proteção desses direitos e para além das instituições colocadas até hoje como garantes desses. Nesse sentido, a partir de um novo sujeito dos direitos humanos, qual seja, o "comum", se busca construir um novo arranjo cosmopolita que se desligue dos pressupostos antropológicos que constroem o sujeito cosmopolita na modernidade, e o disseminam na contemporaneidade universalizando um dado sujeito que se torna dominante. É também necessário, sob o viés do "comum", constituir um cosmopolitismo não institucionalizado, ou seja, um cosmopolitismo enquanto práxis, enquanto movimento e ambiente antagônico e revolucionário de resistência, que se contraponha ao "Império" e ao cosmopolitismo "imperial" que se ergue.

Nessa perspectiva o que se intenta no presente trabalho é apresentar um cosmopolitismo diverso e alternativo que não se confunde com os projetos cosmopolitas "imperiais, pois, tem como 
fundamento e pressuposto central a constituição de um novo sujeito, qual seja, o "comum" que nomeia a "multidão" e implica o vir-a-fala das singularidades na multiplicidade multitudinária desde a colonialidade e para além dela em meio ao "Império" como um movimento de resistência, antagônico e revolucionário. A esse cosmopolitismo, se dá o nome de "comumpolitismo" e/ou “cosmopolitismo do comum" 15 , como condição de possibilidade para um cosmopolitismo da práxis, e não meramente institucionalizado e caracterizado nas relações produzidas pela colonialidade e pela "imperialidade".

Esse novo cosmopolitismo tem a marca de um novo sujeito político-jurídico-social que se coloca como sujeito de direitos, dos direitos humanos, e evidentemente do cosmopolitismo que surge com esse sujeito e os movimentos da multitudo. E, se o "comum" dá o nome à "multidão", ele dá o nome ao cosmopolitismo que se liberta dos pressupostos modernos e das bases pósmodernas e "imperiais" dos projetos cosmopolitas que aparecem desde Kant aos autores contemporâneos. O "comumpolitismo" é o substrato da revolução possível a partir dos sujeitos que se colocam singularmente no "comum", é a condição de possibilidade para a constituição de um espaço-tempo para os direitos humanos para além das instituições que classicamente se mostraram o lugar desses direitos e de determinados sujeitos - pois, nessas instituições clássicas, certos sujeitos não são considerados, sobretudo, na modernidade nascente.

Se no interior do Estado desde a modernidade até a atualidade um sem fim de sujeitos e humanidades foram desconsiderados e até mesmo desintegrados por uma lógica de dominação e exclusão a partir de mecanismos de controle e classificação biopolíticos; no interior do "Império" essas humanidades e sujeitos produzidos na modernidade, pela colonialidade, foram reclassificados e novamente controlados ainda inseridos em um aparato de dominação e exclusão, que agora, radicaliza os mecanismos biopolíticos de controle e constroem um verdadeiro "estado de exceção global" que mantém a divisão "eu" e "outro" e à potencializa ${ }^{16}$.

Desse modo, no "comumpolitismo" a partir do sujeito "comum" que dá o nome "comum" e constitui um "estar-em-comum" é possível albergar todos esses projetos de vida e essas

\footnotetext{
${ }^{15}$ A partir de agora, os termos "comumpolitismo" e "cosmopolitismo do comum" serão utilizados como sinônimos, significando um novo cosmopolitismo que é proposto no presente trabalho a partir das teorias de Antonio Negri e Michael Hardt.

${ }^{16}$ Claramente, no âmbito dos projetos cosmopolitas que inegável e necessariamente se ligam às instituições modernas ou ao "Império", bem como, se constituem ainda sob os alicerces das diferenças humanas e sociais geradas desde a colonialidade à "imperialidade", também se mantém essa estrutura de dominação e exclusão que controla e classifica e continua a manter determinados sujeitos dos direitos humanos, longe desses direitos. Não há no cosmopolitismo contemporâneo lugar para o Sul global como um lugar capaz de produzir sentidos para esse movimento de proteção do humano que se dá cosmopolitamente, como também, e por esse motivo, não há lugar como cosmopolita para o negro, o índio, o homossexual, o árabe, o mulçumano, a mulher, o refugiado, nem para o pobre europeu, para o descendente de imigrantes, ou seja, para o que não seja considerado euro-ocidental e inserido num projeto de vida que se coloca como único possível e albergado por um "conceito" de direitos humanos que admite apenas um humano possível.
} 
humanidades que são colocadas fora da modernidade, do paradigma "imperial”, do cosmopolitismo e dos direitos humanos. Não há mais uma divisão entre grupos de indivíduos e indivíduos e nem uma disputa entre ambos para serem sujeitos dos direitos humanos, todos são sujeitos dos direitos humanos no "comum". O "comum" é o provir das singularidades que se articulam na sua multiplicidade e se manifestam múltiplas e singulares ao mesmo tempo, na arena de luta por direitos, uma luta que cada vez mais é antagônica e revolucionária enquanto conduta de resistência ao aparato "imperial" de controle e exclusão.

Nesse sentido, é por isso que o "comum" cinde com essa divisão e rompe com essa disputa entre quais e quem são efetivamente os sujeitos de direitos e dos direitos humanos, se os indivíduos e/ou os grupos de indivíduos. No "comum" e, assim, no "comumpolitismo" os sujeitos se articulam em suas singularidades não sendo reduzidos ao uno, e ao mesmo tempo em que se mantendo e manifestando múltiplos nas suas singularidades, não colocam essas singularidades em confronto. Não há uma disputa por direitos e pelos direitos humanos entre as singularidades que se movimentam na multitudo, em verdade, há um constante movimento de luta por direitos e resistência aos projetos "imperiais" a partir dessas singularidades que se apropriam constituintemente de uma práxis social antagonista e revolucionária que é condição de possibilidade para o "cosmopolitismo do comum".

“O comum não pode ser encontrado em um "dado primeiro" [...], mas sempre como uma "emergência" que irrompe em âmbito de enfrentamentos e batalhas [...], o comum é produzido em uma dinâmica viva, em um feixe de relações de instável multiplicidade, que não excluem o comum, mas o faz emergir na riqueza política das resistências". (MENDES, 2012, 141-142). Logo, ele constitui o "comumpolitismo" enquanto uma prática, uma emergência constante de sujeitos e direitos que rompem com a dinâmica de classificação, dominação e expropriação empreendida pelo "Império" na contemporaneidade. Nesse ambiente não se institui um modo-de-der único no mundo, nem se institui um feixe institucional capaz de abarcar toda a complexidade desses movimentos multitudinários de ruptura, mas sim, se perfaz diuturnamente um fluxo de direitos e sujeitos que se constituem na práxis, contra a institucionalidade, mas inseridos nela, e assim gerando abalos nas suas estruturas.

Nessa caminhada, não se admite mais posturas que vilipendiam os direitos de alguns em detrimento dos direitos de outros. Não há no interior do "comum" e necessariamente do "comumpolitismo" lugar para diferenciações entre determinados sujeitos/indivíduos ou entre grupos e indivíduos na luta por direitos, porque o "comum” é um “todos-em-comum”, é uma necessária apreensão de que tanto indivíduos quanto grupos de indivíduos têm os seus direitos 
violados, e por isso se encontram em um "plano comum" como expropriados pelo sistema “capitalista-imperial".

Nessa medida, o "comumpolitismo" é a morada dos sujeitos que são relegados pela modernidade, pela estatalidade, pelo cosmopolitismo, pelo "Império", e se conforma como lugar latente dá e na resistência prática em que os direitos humanos são um conteúdo de luta para além da mera positivação (nacional ou internacional). No "comumpolitismo" a "realidade que nos assiste viver como "pobres-explorados" e "sujeitos", devemos invertê-la em "esfera comum da valorização', em "comunismo do capital", realidade da qual podemos nos reapropriar como 'esfera comum do trabalho vivo"”. (NEGRI, 2016a, p. 174). No "comumpolitismo" a força produtiva do(s) "sujeito(s) comum(ns) constitui as relações de produção através da realização do trabalho vivo que instaura a produção de direitos no interior de um "novo cosmopolitismo" que se metamorfoseia enquanto prática constante das forças produtivas e redesenha os limites espaço-temporais dos direitos e dos sujeitos em perspectiva global. (NEGRI, 2016a).

"Chegamos, assim, a um ponto crucial, a partir do qual talvez seja possível dividir, hoje, com muita clareza, políticas da transcendência e políticas da imanência" (NEGRI, 2016a, p.170), e, assim, se pode situar o "comumpolitismo" como uma política da imanência, ou, como um projeto da imanência, que se dá na imanência dos corpos que afetivamente formam a rede de relações humanas que se constitui na realização do trabalho imaterial, e é por excelência um acontecimento da e na imanência do "fazer comum". O “comumpolitismo" não é um projeto que transcendentemente se coloca como algo superior que cria uma superestrutura que solapa a condição humana, nem um projeto que constitui enquanto sujeitos transcendentes determinados seres humanos que detém transcendentemente uma humanidade superior. O "cosmopolitismo do comum" é um trabalho dos afetos que se conectam pelas ações das singularidades numa multiplicidade plural que compartilha um espaço-tempo imanente no fazer-se "multidão".

Não se tem mais um cosmopolitismo na/da transcendência ou na institucionalidade que é construída abstratamente pelo poder soberano como o lugar privilegiado - e euro-ocidental, ou, pan-europeu - para os direitos humanos. É um eterno "fazer(-se)-em-comum" que realiza a possibilidade de romper com os cosmopolitismos anteriores que não dão conta da realidade, pois atuam como fundamento e lugar transcendental de uma humanidade que só existe de maneira abstrata, hegemônica e dominante. O "comumpolitismo" abriga os excluídos e expropriados em uma prática cotidiana de resistência a partir dos direitos humanos e de uma atuação antagonista e revolucionaria das singularidades que se movem multitudinariamente no mundo a partir das relações propiciadas pelo trabalho vivo. 
O “cosmopolitismo do comum” é um espaço-tempo de produção biopolítica ao mesmo tempo em que é biopolítico por excelência, pois, espaço-tempo das relações sociais propiciadas e produzidas no interior do capital enquanto trabalho produtivo vivo. As capacidades humanas se alinham "em-comum" no interior desse novo "fenômeno" ou ambiente que compatibiliza o destino das singularidades com o destino das pluralidades e orienta uma capacidade biopolítica de produzir direitos, para além da mera reprodução do direito moderno ou "imperial". É necessário que se perceba o "comumpolitismo" como condição de possibilidade para os direitos humanos em escala mundial/global, bem como, face ao "Império" e suas formas - nada originais - de produzir guerras e gerar um humanitarismo pan-europeu e nada humanitário, para além de estrategicamente hegemônico.

O "comumpolitismo" assim, é uma institucionalidade sem sê-la, ou, é uma institucionalidade, mas, sempre em aberto, sempre moldada pelas relações da carne nas singularidades que há conformam plural. Nesse sentido, necessariamente o "comumpolitismo" tem uma aparência monstruosa, assim como a multitudo o é, pois, uma instituição - um fenômeno - que está sempre aberto ao plano da imanência e à corporeidade dos sujeitos que o compõe e modificam nas suas movimentações sempre singulares, mas, sempre plurais. É um ambiente de singularidade e pluralidade, e, por isso, não se forma enquanto uma construção abstrata que condiciona as humanidades à determinadas formas e características que às tornam verdadeiramente cosmopolitas.

Passa-se do povo à "multidão", e consequentemente do "cidadão do mundo" ao "comum", que transborda as noções clássicas de cidadão e engloba todos em um plano "comum" que desdobra os arranjos comunitários em um "estar-sempre-em-comum" cooperativo e compartilhado, que produz "um mundo" possível em formações e movimentos multitudinários determinantes de uma modificação das construções subjetivas da modernidade e libertadoras das subjetividades em meio ao "Império". De acordo com Hardt e Negri (2014a), para além do perigo, a monstruosidade da "multidão" se identifica como condição de possibilidade para a mudança e ruptura com o que está posto pela sistemática "imperial", bem como, é a "multidão" a carne e o corpo da resistência, é o campo de luta e é o sujeito antagônico que recebe o "nome comum".

$\mathrm{O}$ "comumpolitismo" necessariamente se origina de uma maneira que "impõe" uma forma de organização social em que "as singularidades sociais controlam através de sua própria atividade biopolítica aqueles bens e serviços que permitem a reprodução da própria multidão". (HARDT; NEGRI, 2014a, p. 268). É nessa forma de organização que o "comum" enquanto sujeito antagonista e revolucionário da resistência se coloca na luta em todo o lugar do "Império" desencadeando uma série de processos de ruptura e combate que impregnam de vivacidade o aparato "imperial" e o 
desestabilizam em direção a um "estar-em-comum" que é a alternativa à modernidade à pósmodernidade que surgem como únicas possibilidades no interior do capitalismo neoliberal.

Seja no Sul global, ou no Norte global, é sempre a luta de um sujeito que recebe o mesmo nome - "comum" - e constitui-se, constituindo a multitudo, se movimentando de maneira monstruosa e multitudinária sem demarcar lideranças ou um agir político certo e determinado. É o sujeito da práxis que engendra um processo de construção da e na práxis de uma política que se mostra diversa das institucionais e sempre atual pois, co-originária e cooperativa comunicando os expropriados e excluídos do mundo, de qualquer mundo.

Nesse sentido, é evidente que o "comum” enquanto sujeito político, enquanto sujeito da luta e da resistência não se pretende enquanto identidade, mas sim, se manifesta enquanto movimento sempre das singularidades na sua multiplicidade. As lutas por direitos dessas diversas identidades que se manifestam expropriadas e excluídas - seja por questões de raça, gênero, etnia, condição econômica, etc. - são mantidas no interior do "comum", e multitudinariamente se colocam como a luta dessas singularidades no e pelo "comum'. O “comum” é o novo sujeito da revolução e é um emaranhado de relações imateriais e vivas que não desmancham as identidades, mas sim às fortalecem na "luta comum" pelos seus direitos.

Nessa perspectiva é necessário, sim, um novo cosmopolitismo que vem marcado pelo "comum" como sujeito que o constitui, sobrepondo-se aos projetos cosmopolitas "imperiais". Há que se pensar assim o "comumpolitismo" como um "cosmopolitismo outro" que abrigue os direitos humanos como direitos das singularidades e não de sujeitos abstratos. O "comum" e a sua força imprime no "comumpolitismo" a força da imanência e da realidade social como realidade de luta e como plano antagonista em relação ao "Império", ao Estado e ao cosmopolitismo imperial que torna alguns, cidadãos do mundo, e sujeita outros à uma condição de imobilidade. Há um devir imanente no "cosmopolitismo do comum", há uma força constantemente renovada que renova esse novo cosmopolitismo e o centra como condição de possibilidade para o "acontecer comum da humanidade".

O "comumpolitismo" é a garantia de que a multitudo pode se movimentar no mundo tendo direitos garantidos e abrigada sob um paradigma de direitos humanos que também é imanente e, assim, se torna realidade social, singular e plural ao mesmo tempo. Se percebe a partir da constituição do "comumpolitismo" e da ação do "comum" uma nova economia de pensamento, uma constituição econômica moldada pelo trabalho imaterial e percebida nas movimentações de ruptura e resistência da multitudo. O "comum" implica no "comumpolitismo" como uma esfera comunicacional entre singularidades plurais que ali se manifestam inteiramente, pois, em meio a 
um novo arranjo que possibilita a sua visualização enquanto sujeitos de direitos e dos direitos humanos.

A ação da "multidão do comum" desvela e ao mesmo tempo desarticula, pois, revela, a ação do "Império" e seu biopoder que a partir do uso da violência busca o controle biopolítico dos corpos, da carne, da potência que emana das relações sociais que conformam a realizam do "estar-emcomum" que guia os movimentos antagônicos de luta e resistência que eclodiram desde Lacandona, passando por Gênova e Cochabamba e chegando à Tahrir e Zuccotti Park (NEGRI, 2002). "É a constituição que nasce da militância de homens construídos no trabalho imaterial e cooperativo, decididos a viver como associação subversiva”. (NEGRI, 2003, p. 216).

Desse modo, se coloca de maneira evidente a necessidade de se pensar e constituir um novo lugar para os direitos humanos em que toda a sua extensão e conteúdo sejam privilegiados e garantidos de maneira igual a todo e qualquer ser humano. Nesse momento, os direitos humanos são sim o conteúdo da luta e o motivo dela mesma, são a possibilidade de ruptura com as práticas "imperiais" e condição para a construção de um paradigma jurídico-político-social baseado na solidariedade, na pluralidade e no vir a fala das singularidades. Não há mais espaço para uma concepção estreita de direitos humanos, que percebe como sujeitos do humanismo e do humanitarismo apenas os "homens civilizados" euro-ocidentais.

O "comumpolitismo" é o lugar da crítica ao cosmopolitismo, aos direitos humanos, aos limites do Estado e aos exageros do "Império", mas é também o lugar dos direitos humanos repensados e das singularidades compreendidas em sua multiplicidade, como um movimento multitudinário que se orienta na virtude de "ser-em-comum" constituindo uma dimensão que é constitutiva dos direitos humanos. O novo sujeito que lança no mundo como um sujeito da ruptura, o sujeito que traz no "nome comum" é o sujeito que possibilita essa movimentação que desestabiliza o "Império" e a partir das suas estruturas cria uma nova perspectiva para os sujeitos e para os direitos humanos.

Assim, o "comumpolitismo" se mostra como uma necessidade, uma necessidade que é latente como um novo lugar que dentro do "Império" o refunda e o coloca em cheque tendo como articulador desse processo o "comum" como um novo sujeito dos direitos humanos. Em meio ao "comumpolitismo" as singularidades se mostram múltiplas e instituem um espaço-tempo solidário, plural e includente, em que as marcas distintivas da Modernidade/modernidade que são potencializadas no âmbito "imperial" se apagam e constituem uma humanidade renovada que se permite em toda a sua diferença e pluralidade, em todas as suas formas e em todos os seus sentidos, constituindo um novo paradigma de luta, resistência e antagonismo que é constituído por essas humanidades e às constitui e desvela em meio ao "cosmopolitismo do comum". 


\section{CONCLUSÃO}

Também fica evidente que, em meio ao paradigma "imperial" que se manifesta sim, por meio desse estado de guerra global, enquanto um verdadeiro estado de exceção permanente que se estrutura a partir de uma biopolítica dá e para a morte, o cosmopolitismo vindo desde Immanuel Kant e chegando à Otfried Höffe se mostra como um projeto que é insuficiente e deficitário, pois, quando o "outro" é visto como inimigo e indistintamente considerado um não-humano, não é possível ser cosmopolita, a não ser, sob uma perspectiva "imperial" que necessariamente será excludente e seletiva. O que se quer deixar claro aqui, é que o projeto cosmopolita pensado por Kant e reformulado por Höffe, não é possível a não ser estando a serviço do "Império".

$\mathrm{O}(\mathrm{s})$ cosmopolitismo(s) que se configuram nessa parte da história, são projeto dominantes que delimitam euro-ocidentalmente quem são os "cosmopolitas", ou, quem são os "cidadãos do mundo". Determina-se de forma excludente quem são os seres humanos aos quais deve ser concedido o direito de visitação presente no cosmopolitismo kantiano, bem como, quais são os cidadãos da República Mundial höffniana, ou seja, se orquestram projetos dominantes que produzem exclusão, dominação, e necessariamente a catalogação de indivíduos como mais, ou, menos humanos.

Nesse ponto, os direitos humanos se colocam como fundamento desses projetos, evidentemente sob uma perspectiva distorcida e ligada ao paradigma hegemônico-dominante de direitos humanos, que descentra da humanidade do próprio homem, construída dia-a-dia como prática libertadora a fundamentação dos direitos humanos enquanto conteúdo e estrutura(s) protetivas. Os direitos humanos recebem uma roupagem que deve vestir qualquer ser humano, e que os que não são vestidos por tal roupagem, restam excluídos do conteúdo desses direitos, bem como, estão colocados fora das esferas de proteção e garantia desses direitos, seja à nível nacional ou internacional.

Nessa perspectiva, pode-se apontar duas possibilidades para o cosmopolitismo: ou, ele se coloca junto e a serviço do "Império" e se torna um cosmopolitismo não cosmopolita, a não ser para alguns seres humanos, que humanamente superiores desfrutam da condição de ser cosmopolita ou cidadão do mundo - cidadão mundial - pois, fazem parte do projeto humanitário/humanista euroocidental que se mostra dominante, hegemônico e superior; ou, então um cosmopolitismo que, embora, se pretenda cosmopolita e não se coloque sob a égide do paradigma "imperial", também não consegue se impor como uma alternativa, nem como um espaço-tempo de luta e resistência frente ao "Império". Nesse ponto, os direitos humanos perdem o seu lugar de proteção e 
concretização para além do estatalismo, bem como, não encontram nenhum outro ambiente que os possa dar guarida em meio ao avanço "imperial" sobre a humanidade.

Nesse contexto, o cosmopolitismo seja em Kant, seja em Höffe, está ligado ao estatalismo, e por consequência, acaba por ficar integrado e inserido no interior do "Império", bem como, os demais projetos de cosmopolitismo que surgem na atualidade. $O$ cosmopolitismo não se coloca como um ponto de ruptura e de repensar das práticas "imperiais", mas por fim, acaba sendo cooptado pelas estruturas "imperiais", e não consegue conferir ao ser humano para além do padrão imperial - moderno-europeu-ocidental - condições de garantia, proteção e concretização dos seus mais elementares direitos.

Dessa forma o "comum" articula e se articula um movimento revolucionário e antagonista de resistência ao "Império" inserido e se aproveitando das próprias estruturas "imperiais". O movimento da "multidão do comum" é interno às estruturas "imperiais" buscando o abalo por dentro do próprio "Império" minando as suas práticas de exclusão e expropriação, com práticas de inclusão e pertença ao mundo, no sentido de construção de outros mundos possíveis, que conservam os sujeitos em suas pluralidades e os permitem o movimento libertador da multitudo que constituí o "comum".

Logo, pode-se a partir do "comum" como sujeito, imaginar-se, pensar-se e constituir-se um novo cosmopolitismo, o "cosmopolitismo do comum" ou "comumpolitismo", que é um cosmopolitismo da imanência, que se dá a partir dos sujeitos e não das instituições, que se movimenta a partir da "multidão do comum" e não dos indivíduos percebidos como humanos ou não-humanos, mas, principalmente, um cosmopolitismo da potência e não do poder. $\mathrm{O}$ "comumpolitismo" se origina da potência das singularidades que na sua multiplicidade não se anulam e não anulam a luta pelos direitos humanos que é singular e plural ao mesmo tempo. Assim, se pode afirmar que é possível constituir o "comumpolitismo" como um "lugar" para os direitos humanos e para as humanidades expropriadas e excluídas, face ao "Império".

\section{BETWEEN KANT AND NEGRI: A PATH FROM COSMOPOLITANISM TO "COMMONPOLITANISM"}

ABSTRACT: This paper aims to analyze the path to be tracked from Kantian cosmopolitanism to what is called "commonpolitanism" as a new place for human rights today. In this case, we seek to show the modern, limited and exclusive bases of the cosmopolitan projects by Immanuel Kant and Otfried Höffe, determining their connection with statism and their apprehension by the "Empire", besides proposing an alternative cosmopolitan project. Thus, starting from the theoretical 
construction of Antonio Negri and the idea of "common" as a new political subject from the "multitude", we propose the construction of "commonpolitanism" or "cosmopolitanism of the common" as an alternative, inclusive, collective and plural cosmopolitan project conformed in the daily practice of the "multitude", establishing itself as a new place for human rights and movements of the "multitude of the common" as revolutionary, antagonistic and resistance practices. In this sense, we aim to present "commonpolitanism" as a possible project and as an environment for human rights today, as opposed to state or "imperial" cosmopolitan projects. Therefore, we chosen as approach the analectic method as a method that comes from the other as totally free, as the other beyond the total system understood dialectically in the (modern/postmodern) movement.

KEYWORDS: Cosmopolitanism. "Commonpolitanism". “Common”. Human rights.

\section{REFERÊNCIAS}

ALONSO, Fernando H. Llano. El humanismo cosmopolita de Immanuel Kant. Madrid: Dykinson, 2002.

BENHABIB, Seyla. Los derechos de los otros: extranjeros, residentes y ciudadanos. Tradução: Gabriel Zadunaisky. Barcelona: Gedisa, 2004.

BRAGATO, Fernanda. Para Além do Discurso Eurocêntrico dos Direitos Humanos: contribuições desde a descolonialidade. Revista Novos Estudos Jurídicos, Itajaí, v. 19, n. 1, p. 201-23, jan-abr. 2014.

BRAGATO, Fernanda. Discursos Desumanizantes e Violação Seletiva de Direitos Humanos Sob a Lógica da Colonialidade. Revista Quaestio Iuris, Rio de Janeiro, v. 9, n. 4, p. 1806-1823, outdez. 2016.

GAZOLLA, Rachel. O ofício do filósofo estóico: o duplo registro do discurso as Stoa. São Paulo: Loyola, 1999.

GOYARD-FABRE, Simone. Filosofia crítica e razão jurídica. Tradução: Maria Ermantina de Almeida Prado Galvão. São Paulo: Martins Fontes, 2006.

GOULET-CAZÉ, Marie-Odile; BRANHAM, R. Bracht. Os cínicos: o movimento cínico da antiguidade e o seu legado. Tradução: Cecília Camargo Bartalotti. São Paulo: Loyola, 2007.

GROSFOGUEL, Ramon. Hacia Un Pluri-Versalismo Transmoderno Decolonial. Revista Tabula Rasa, Bogotá, n. 9, p. 199-215, jul-dez. 2008.

GROSSMANN, Elias. Paz e República Mundial: de Kant à Höffe. Porto Alegre: PUC/RS, 2006, 197 p. Tese (Doutorado) - Programa de Pós-Graduação em Filosofia, Pontifícia Universidade do Rio Grande do Sul, Porto Alegre, 2006.

HARDT, Michael; NEGRI, Antonio. Império. Tradução: Berilo Vargas. Rio de Janeiro: Record, 2002.

HARDT, Michael; NEGRI, Antonio. Multidão: guerra e democracia na era do Império.

Tradução: Giuseppe Cocco. Rio de Janeiro: Record, 2014a. 
HARDT, Michael; NEGRI, Antonio. Bem Estar Comum. Tradução: Clóvis Marques. Rio de Janeiro: Record, 2016.

HARDT, Michael; NEGRI, Antonio. Declaração - isto não é um manifesto. Tradução: Carlos Szlak. São Paulo: N-1, 2014b.

HÖFFE, Otfried. A Democracia no mundo de hoje. Tradução: Tito Lívio Cruz Romão. São Paulo: Martins Fontes, 2005.

HÖFFE, Otfried. Justiça política. São Paulo: Martins Fontes, 2006.

HÖFFE, Otfried. Derecho intercultural. Tradução: Rafael Sevilla. Barcelona: Gedisa, 2008.

HÖFFE, Otfried. O que é justiça?. Tradução: Peter Neumann. Porto Alegre: EDPUCRS, 2003b.

HÖFFE, Otfried. Visão República Mundial: democracia na era da globalização. Tradução: Celso de Moraes Pinheiro. In: SOUZA, Draiton Gonzaga de; OLIVEIRA, Nythamar Fernandes (Org). Justiça e Política: homenagem a Otfried Höffe. Porto Alegre: EDPUCRS, 2003a, p. 205-224.

KANT, Immanuel. À paz perpétua. Tradução: Marco Zingano. Porto Alegre: LP\&M, 2010b.

KANT, Immanuel. Rumo à paz perpétua. Tradução: Heloísa Sarzana Pugliesi. São Paulo: Ícone, 2010a.

KANT, Immanuel. Ideia de uma Historia Universal de um Ponto de Vista Cosmopolita. Tradução: Rodrigo Naves; Ricardo R. Terra. In: TERRA, Ricardo R. (Org). Ideia de uma historia universal de um ponto de vista cosmopolita. São Paulo: Martins Fontes, 2011, p. 1-22.

KANT, Immanuel. Doutrina do Direito. Tradução: Edson Bini. São Paulo: Ícone, 2013.

KANT, Immanuel. A metafísica dos costumes. Tradução: Edson Bini. Bauru: EDIPRO, 2008.

MENDES, Alexandre Fabiano. Para além da "Tragédia do Comum". Conflito e produção de subjetividade no capitalismo contemporâneo. Rio de Janeiro: UERJ, 2012, 190 p. Tese (Doutorado) - Programa de Pós-Graduação em Direito, Universidade do Estado do Rio de Janeiro, Rio de Janeiro, 2012.

NASCIMENTO, Valéria Ribas do. O Tempo das Reconfigurações do Constitucionalismo: os desafios para uma cultura cosmopolita. São Paulo: LTr, 2011.

NEGRI, Antonio. Espinosa subersivo e outros escritos. Tradução: Herivelto Pereira de Souza. Belo Horizonte: Autêntica, 2016a.

NEGRI, Antonio. Marx além de Marx: caderno de trabalho sobre os Gundrisse. Tradução: Bruno Cava. São Paulo: Autonomia Literária, $2016 b$.

NEGRI, Antonio. 5 lições sobre o império. Tradução: Alba Olmi. Rio de Janeiro: DP\&A, 2003. 
NEGRI, Antonio. Assim Começou o Fim do Império. In: COCCO, Giuseppe; HOPSTEIN, Graciela (Org). As multidões e o império: entre globalização da guerra e universalização dos direitos. Rio de Janeiro: DP\&A, 2002, p. 95-106.

NOUR, Soraya. À Paz Perpétua de Kant: filosofia do direito internacional e das relações internacionais. São Paulo: Martins Fontes, 2013.

SALDANHA, Jânia Maria Lopes. Cosmopolitismo jurídico: teorias e práticas de um direito emergente entre a globalização e a mundialização. Porto Alegre: Livraria do Advogado, 2018.

ZANELLA, Diego Carlos. O cosmopolitismo kantiano: do melhoramento dos costumes humanos à instituição da paz. Porto Alegre: PUC/RS, 2012, 155 p. Tese (Doutorado) - Programa de Pós-Graduação em Filosofia, Pontifícia Universidade do Rio Grande do Sul, Porto Alegre, 2012.

Trabalho enviado em 15 de agosto de 2019

Aceito em 26 de fevereiro de 2020 